\title{
Recycling of crustal material by the Iceland mantle plume: new evidence from nitrogen elemental and isotope systematics of subglacial basalts
}

Sæmundur A. Halldórsson ${ }^{1}$, David R. Hilton ${ }^{1}$, Peter H. Barry ${ }^{1,2}$, Evelyn Füri ${ }^{1,3}$ and Karl Grönvold ${ }^{4}$

1: Fluids and Volatiles Laboratory, Geosciences Research Division, Scripps Institution of Oceanography, University of California, San Diego, La Jolla, CA 92093-0244, USA

2: Now at Department of Earth Sciences, Oxford University, UK

3: Now at Centre de Recherches Pétrographiques et Géochimiques, CNRS-UL, 15 rue Notre-Dame des Pauvres, BP20, 54501 Vandoeuvre-lès-Nancy Cedex, France

4: Nordic Volcanological Center, Institute of Earth Sciences, University of Iceland, Askja, Sturlugata 7, 101 Reykjavík, Iceland

*Corresponding Author: saemiah@hi.is

Present address: Nordic Volcanological Center, Institute of Earth Sciences, University of Iceland, Askja, Sturlugata 7, 101 Reykjavík, Iceland

Number of words:

Abstract text: 425

Main text: 9,011

Number of Figures: 9

Number of Tables: 2

Number of Supplementary Tables: 2 


\section{Abstract}

We report new nitrogen $\left(\mathrm{N}_{2}\right)$ abundance and isotope $\left(\delta^{15} \mathrm{~N}\right)$ data for 43 subglacial basaltic glasses from the neovolcanic zones of Iceland, a key locality in studies of mantle plume geochemistry and crust-mantle processes. New helium and argon abundance and isotope data are also reported to supplement previous studies (Füri et al., 2010; Barry et al., 2014), allowing elemental ratios (e.g., $\mathrm{N}_{2} /{ }^{40} \mathrm{Ar}^{*}$ where ${ }^{40} \mathrm{Ar}^{*}=$ radiogenic ${ }^{40} \mathrm{Ar}$ ) to be calculated. Subglacial basaltic glasses with $\mathrm{N}_{2}>2 \mu \mathrm{cm}^{3} \mathrm{STP} / \mathrm{g}$ show a wide range in $\delta^{15} \mathrm{~N}$ values, from -2.91 to $+11.96 \%$ (vs. Air), with values $>6 \%$ only observed at one locality in the Eastern Rift Zone. Elemental ratios involving $\mathrm{N}_{2}$, i.e., $\mathrm{N}_{2} /{ }^{3} \mathrm{He}$, and $\mathrm{N}_{2} /{ }^{40} \mathrm{Ar} *$, span several orders of magnitude from $2.5 \times 10^{5}$ to $9.0 \times 10^{7}$, and 32.8 to $1.46 \times 10^{6}$, respectively. In contrast, argon isotope ratios $\left({ }^{40} \mathrm{Ar} /{ }^{36} \mathrm{Ar}\right)$ are limited, ranging from air-like ( 298.6) values up to 1330 . Glasses exhibit a wide range in helium isotope ratios $\left(8-26 \mathrm{R}_{\mathrm{A}}\right)$, with clear distinctions between individual rift segments.

A number of processes have extensively modified original mantle source $\mathrm{N}$ isotope and relative abundance compositions - most significantly air interaction, crustal contamination in some instances, and possibly degassing-induced fractionation. Under the assumption that the starting ${ }^{4} \mathrm{He} /{ }^{40} \mathrm{Ar} *$ production ratio of Iceland mantle is identical to the depleted MORB mantle (DMM), a filtering protocol for the entire $\mathrm{N}$ dataset, based upon ${ }^{40} \mathrm{Ar} /{ }^{36} \mathrm{Ar}$ and ${ }^{4} \mathrm{He} /{ }^{40} \mathrm{Ar} *$ ratios, was adopted to identify samples with unmodified $\delta^{15} \mathrm{~N}$ values. Consequently, we identify 22 samples that define the Icelandic mantle $\mathrm{N}$-isotope distribution $\left(\delta^{15} \mathrm{~N}=-2.29\right.$ to $+5.71 \%$ ). Using the filtered dataset, we investigate simple binary mixing scenarios involving $\mathrm{N}_{2} /{ }^{3} \mathrm{He}-\mathrm{N}_{2} /{ }^{40} \mathrm{Ar} *-\delta^{15} \mathrm{~N}$ variations to identify mantle end-member compositions. Mixing scenarios are consistent with a recycled component in the Iceland mantle source, defined by a high and heterogeneous $\delta^{15} \mathrm{~N}$ end-member. Moreover, this endmember is coupled to the high ${ }^{3} \mathrm{He} /{ }^{4} \mathrm{He}$ signature, and is characterized by He depletion and/or 

90

the presence of excess $\mathrm{N}_{2}$. These features strongly suggest the presence of recycled crustal $\mathrm{N}$ component(s) integrated into and/or entrained by the Iceland plume source.

These new results reveal the highly heterogeneous nature of nitrogen in the hybrid Iceland plume source, consistent with models based on trace elements and radiogenic isotopes that advocate for significant heterogeneity of recycled crustal component(s) sampled by the Iceland plume. A relatively young age of the recycled crustal material (possibly Phanerozoic) is consistent with the association of positive $\delta^{15} \mathrm{~N}$ values and high $\mathrm{N}_{2} /{ }^{40} \mathrm{Ar} *$ ratios with constraints from radiogenic isotopes (e.g., $\mathrm{Pb}$ ), thus indicating a relatively short time-interval $\left(\sim 10^{8}\right.$ years) between subduction of crustal material and entrainment by the Iceland mantle plume. 85 86 8 89

.




\section{Introduction}

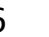

Nitrogen is the most abundant gas in the atmosphere, and is found in substantial quantities (up to \% levels) in near-surface low temperature environments, such as biomass, soils and the oceans; however, it is present at trace levels only $(<1 \mathrm{ppm})$ in Earth's mantle (Marty, 1995; Bebout et al., 2013; Johnson and Goldblatt, 2015). Such an extensive abundance difference between the mantle and surface is also accompanied by relatively large nitrogen isotopic contrasts, which has prompted numerous studies exploiting nitrogen as a tracer for volatile recycling from the surface (e.g., Sano et al., 1998; Fischer et al., 2002; Marty and Dauphas, 2003a). However, little is known of the extent of nitrogen recycling into the deep(er) mantle, i.e., the mantle beyond the zone of arc magma generation (e.g., Cartigny and Marty, 2013): indeed, it remains uncertain how recycling of surficial material has affected the isotopic composition of nitrogen and its budget in shallow (upper mantle) versus deeper mantle reservoirs (Marty, 2012; Bebout et al., 2013; Busigny \& Bebout, 2013; Cartigny \& Marty, 2013; Johnson and Goldblatt, 2015).

In this contribution, we assess the hypothesis that nitrogen can identify 'deep recycling' of subduction-related material by targeting a mantle plume (Iceland) characterized by an almost ubiquitous high ${ }^{3} \mathrm{He} /{ }^{4} \mathrm{He}$ signature (e.g., Polak et al., 1976; Kurz et al, 1985; Condomines et al, 1983; Hilton et al., 1990; Poreda et al., 1992), generally regarded as a particularly sensitive tracer of mantle material isolated from the upper mantle reservoir and, by inference, located in the lowermost mantle (e.g., Craig and Lupton, 1976; Kurz et al., 1982; Courtillot et al., 2003). Iceland is one of the few hotspot localities where the nitrogen isotopic signature of high ${ }^{3} \mathrm{He} /{ }^{4} \mathrm{He}$ material can be studied in detail due to the presence of extensive occurrences of rapidly-quenched pillow rims of subglacial basalts found throughout Iceland. Such material contains nitrogen captured under different confining pressures (e.g., 
Tuffen et al., 2010), and thus records varying degrees of magmatic degassing. Targeting hyaloclastic glasses therefore also permits investigation of secondary controls on elemental and isotope variability in the nitrogen systematics, such as volatile degassing and interactions with Icelandic crust, which have the potential to perturb primary the $\mathrm{N}$-isotope features of the Icelandic mantle source region during transport of $\mathrm{N}$ to the surface.

\section{Geological setting and samples}

Iceland represents a significant $\left(\sim 100,000 \mathrm{~km}^{2}\right)$ subaerial segment of the Mid-Atlantic Ridge reflecting enhanced lithosphere thickness due to anomalous melting associated with a mantle hotspot (e.g., Bjarnason and Schmeling, 2009). The present-day on-land volcanic activity occurs in two types of neovolcanic zones (Figure 1); (i) the axial rift zone, comprising the Western (WRZ), Eastern (ERZ) and Northern (NRZ) Rift Zone segments, which erupts lavas of tholeiitic composition, and passes through Iceland connecting the adjacent submarine Reykjanes and Kolbeinsey ridges, and (ii) off-rift volcanic flank zones, which erupt lavas of transitional-alkalic to alkalic composition, and include the Snæfellsnes Volcanic Zone (SNVZ), the South Iceland Volcanic Zone (SIVZ), and the Öræfajökull Volcanic Zone (OVZ) (e.g., Jakobsson et al., 2008). For this study, we targeted 43 subglacially-erupted basalts from different localities, divided between the WRZ ( $\mathrm{n}=11), \mathrm{ERZ}$ $(n=12), \operatorname{NRZ}(n=15)$, and the SIVZ $(n=5)$. Sample details and locations are given in Füri et al. (2010) as well as in Tables S1 and Table S2 (see Supplementary Material) with locations shown in Figure 1.

The samples of this study were selected from a larger suite $(n=106)$ of subglacial basaltic glasses from different locations within the neo-volcanic zones which were analyzed for helium abundance and isotope characteristics (Macpherson et al., 2005; Füri et al., 2010; 
this work) as an essential prerequisite to help identify volatile-rich samples for $\mathrm{N}$ abundance and isotope measurements. Indeed, we supplement the database of Macpherson et al. (2005) and Füri et al. (2010) with new He abundance and isotopes characteristics on 16 subglacial glass samples from the volcanic flank zones (Table S1) as well as new Ar abundance and isotopes characteristics on 9 samples (Table S2). Analytical details are given in footnotes of Tables S1 and S2.

All the subglacial basaltic glasses analyzed in this study belong to the so-called Móberg formation (e.g., Jakobsson and Gudmundsson, 2008) - a general term for Icelandic volcanic rocks formed in single vent and/or fissure eruptions during the Brunhes geomagnetic epoch at the end of the Pleistocene (0.78-0.01 Ma) (Jóhannesson and Sæmundsson, 1998). Samples are fresh (i.e., free of any surficial alteration), which suggests relatively young formation ages within the epoch. This is consistent with field observations and cosmogenic exposure ages (Licciardi et al., 2007). All samples are tholeiitic in composition with the exception of those from the South Iceland Volcanic Zone (i.e., TRI-1, TRI-2, TRI-3, BHE-43 and BHE-44), which are transitional-alkalic to alkalic in composition.

\section{Analytical techniques}

\subsection{Nitrogen analysis by in-vacuo crushing}

Nitrogen isotopes and abundances were measured in helium-rich (13.04 to $3447 \times 10^{-9}$ $\mathrm{cm}^{3} \mathrm{STP} / \mathrm{g}$ ) basaltic glasses $\left(\mathrm{n}=43\right.$ ) with ${ }^{3} \mathrm{He} /{ }^{4} \mathrm{He}$ ratios between 8.5 and $25.7 \mathrm{R}_{\mathrm{A}}$ (where $\mathrm{R}_{\mathrm{A}}=$ air ${ }^{3} \mathrm{He} /{ }^{4} \mathrm{He}$ ) and ${ }^{40} \mathrm{Ar} /{ }^{36} \mathrm{Ar}$ ratios between 292.7 and 1335 (Table 1). Using a binocular microscope, fresh glass chips, free of phenocrysts and any visible surficial alteration or large vesicles, were selected. The glass was then ultrasonically cleaned in a 1:1 acetone-methanol 
mixture and dried for $\sim 24$ hours. Between 1 and $3 \mathrm{~g}$ of fresh glass chips were loaded into screw-type crushers (constructed from modified Nupro vacuum valves; see Stuart et al., 1994), evacuated to Ultra-High-Vacuum (UHV), and kept at $\sim 100^{\circ} \mathrm{C}$ overnight. Nitrogen abundances and isotope ratios were determined on a modified VG5440 mass spectrometer, optimized for static triple collection of nitrogen (see Craig et al., 1993; Barry et al. 2012 for details). A description of the purification system used to prepare the samples for $\mathrm{N}$-isotope measurement is given by Barry et al. (2012). In order to maximize nitrogen gas yields, gases were released from samples by single-step crushing in vacuo using an external hydraulic press capable of 5 tons pressure. A direct measurement of $\mathrm{N}_{2} /{ }^{40} \mathrm{Ar}$ was obtained using a quadrupole mass spectrometer on an isolated aliquot of gas released during the crushing procedure (Barry et al., 2012) which we utilized, along with measured ${ }^{40} \mathrm{Ar} /{ }^{36} \mathrm{Ar}$ values, to calculate $\mathrm{N}_{2} /{ }^{40} \mathrm{Ar}$. This direct measurement approach has the advantage over combining individual measurements of $\mathrm{N}_{2}$ and Ar content made during isotopic analyses whereby separate aliquots of sample glass may have different volatile contents as a result of heterogeneous distributions of vesicles.

A standard of pure $\mathrm{N}_{2}$, calibrated relative to Scripps-pier air, was repeatedly measured throughout the run of the Iceland sample set (generally 10-15 times per day). In addition, repeated measurements $(n=12)$ of the Scripps-pier air standard, following exactly the same analytical protocol as adopted for samples, and run weekly, allowed evaluation of uncertainties associated with both sample purification and mass spectrometer measurements. We consider the average $\delta^{15} \mathrm{~N}$ reproducibility of the Scripps-pier air standard value $( \pm 0.48 \%$ $[1 \sigma])$ as the best estimate of the external reproducibility.

Following protocols identical to those described by Barry et al. (2012), procedural $\mathrm{N}_{2}$ blanks were run prior to each individual sample and averaged $3.3 \pm 1\left(\times 10^{-6}\right) \mathrm{cm}^{3} \mathrm{STP}$ for $\mathrm{N}_{2}$ and $13.3 \pm 5.6 \%$ for $\delta^{15} \mathrm{~N}$. Blank contributions were (significantly) less than $20 \%$ of sample 
yields in most cases. For samples that yielded blank contributions $>20 \%(\mathrm{n}=12)$, owing to low intrinsic gas contents and/or small sample sizes, results are listed in italics in Table 1. Below, we focus the discussion only on data that have $<20 \%$ blank contribution

\section{Results}

The combined N-Ar-He isotope and relative abundance characteristics of the 43 subglacial basaltic glasses that are the focus of this study are reported in Table 1, together with measured $\mathrm{N}_{2} /{ }^{40} \mathrm{Ar}$ and derived elemental ratios, $\mathrm{N}_{2} /{ }^{3} \mathrm{He}$, and $\mathrm{N}_{2} /{ }^{40} \mathrm{Ar} *$. New helium $(n=16)$ and argon $(n=9)$ isotope and abundance data from the volcanic flank zones (SIVZ and SNVZ) are reported in Tables S1 and S2, respectively (see Supplementary Material).

\subsection{Nitrogen abundances and isotopes}

To test the reproducibility and the crushing efficiency of our system, we ran duplicates of 12 samples: MID-1, A2, A9, NAL-263, NAL-356, NAL-828, HRD-1, A21/ICE08R-16, A22/ICE08R-17, A35, ICE08R-13, TRI-1. Six duplicates of MID-1 show good agreement in $\left[\mathrm{N}_{2}\right]$ ranging from 21.1 to $31.7\left(\times 10^{-6} \mathrm{~cm}^{3} \mathrm{STP} / \mathrm{g}\right)$ with an average value of $25.9 \pm 4.6\left(\times 10^{-6}\right.$ $\left.\mathrm{cm}^{3} \mathrm{STP} / \mathrm{g}\right)$. These results indicate that the majority of the $\left[\mathrm{N}_{2}\right]$ is released from vesicles in a single crushing step. Our results fall within the range of 13.4 to $58.2\left(\times 10^{-6}\right) \mathrm{cm}^{3} \mathrm{~N}_{2} \mathrm{STP} / \mathrm{g}$ obtained previously on samples from the same outcrop (i.e., DICE-10 and DICE-11 from Miðfell/Dagmálafell: Marty and Dauphas, 2003a). In contrast, out of the other 11 duplicates, several $(n=8)$ samples show poor agreement in $\left[\mathrm{N}_{2}\right]$ : for example, sample NAL-263 gave $\left[\mathrm{N}_{2}\right]$ of 45.5 and $83.8\left(\times 10^{-6}\right) \mathrm{cm}^{3} \mathrm{STP} / \mathrm{g}$ for similar sample loads of 2.537 and 2.105 grams, 
respectively. This suggests that $\left[\mathrm{N}_{2}\right]$ may reflect variable amounts of volatile-rich vesicles within individual samples.

However, there is good agreement in $\delta^{15} \mathrm{~N}$ values of duplicate runs. In the case of NAL-263, the duplicate runs yielded $\delta^{15} \mathrm{~N}$ values of +3.70 and $+4.71 \%$. With respect to MID1, we obtained a range of values for $\delta^{15} \mathrm{~N}$ of the 6 duplicates: from +0.65 to $+3.72 \%$.

Significantly, Marty and Dauphas (2003a) reported multiple crushing steps of samples DICE10 and DICE-11 (i.e., MID-1 = Miðfell/Dagmálafell) with the overall range of values lying between -1.50 to $+3.26 \%$ for $\delta^{15} \mathrm{~N}$, which overlaps with the range of values obtained here. For all duplicates, we only discuss (and plot) $\delta^{15} \mathrm{~N}$ values that had the lowest blank contribution, assuming that they better represent primary $\delta^{15} \mathrm{~N}$ values.

Nitrogen concentrations $\left(\left[\mathrm{N}_{2}\right]\right)$ of the Iceland basalts vary from 2.6 to $83.2\left(\times 10^{-6}\right)$ $\mathrm{cm}^{3} \mathrm{STP} / \mathrm{g}$ (Figure 2). This range is comparable to that reported previously for MORB glasses $\left(\sim 0.4\right.$ to $\left.\sim 118\left(\times 10^{-6}\right) \mathrm{cm}^{3} \mathrm{STP} / \mathrm{g}\right)$, but significantly lower than the overall range reported for OIB glasses $\left(\sim 2\right.$ to $\left.\sim 2970\left(\times 10^{-6}\right) \mathrm{cm}^{3} \mathrm{STP} / \mathrm{g}\right)$ (Marty and Humbert, 1997; Marty and Zimmerman, 1999; Marty and Dauphas, 2003a).

Figure $2 \mathbf{b}$ shows the $\mathrm{N}$ isotope values $\left(\delta^{15} \mathrm{~N}\right)$ versus $\left[\mathrm{N}_{2}\right]$ of the Iceland sample-set together with the MORB and OIB database obtained previously using in vacuo crushing (Marty and Humbert, 1997; Marty and Zimmerman, 1999; Marty and Dauphas, 2003a). Iceland $\delta^{15} \mathrm{~N}$ values show a wide range, from -2.91 to $+11.96 \%$, with little apparent spatial control as different segments of the neovolcanic zones have overlapping $\delta^{15} \mathrm{~N}$ values: this stands in marked contrast to the He isotope distribution in Iceland where there is regionality in the He isotope record (Hilton et al., 1990; Füri et al., 2010). The average $\delta^{15} \mathrm{~N}$ value of +1.6 $\pm 2.8 \%$ o $(1 \sigma, \mathrm{n}=43)$ is significantly higher than the postulated depleted MORB mantle (DMM) end-member value of $-5 \pm 2 \%$ (Marty and Dauphas, 2003a) and the average value we obtained from the MORB database when only considering samples with DMM-type helium 
isotopes (-2.0 $\pm 2.8 \%$ : Marty and Humbert, 1997; Marty and Zimmerman, 1999; Marty and

Dauphas, 2003a). We note that values $>6 \%$ are only observed for one sample located in the Eastern Rift Zone (A35-Sigalda): removing this sample reduces the overall range to -2.9 to

247 $+5.6 \%$, and the mean value to $+1.3 \pm 2.2 \%$. Thus, the Iceland data are in excellent agreement with $\delta^{15} \mathrm{~N}$ values previously reported for OIB glasses which range between -3.2 to $+6.7 \%$ o with a mean value of $+1.9 \pm 2.4 \%$ (Marty and Humbert, 1997; Marty and Zimmerman, 1999; Marty and Dauphas, 2003a).

Existing nitrogen isotope values on Icelandic lavas are limited, with only two reports of samples ( $n=3)$ measured by vacuum crushing (Marty \& Dauphas, 2003a - see above; Fischer et al., 2005). Fischer et al. (2005) obtained a $\delta^{15} \mathrm{~N}$ of $-8 \%$ for a single Iceland phenocryst sample from Theistareykir in the NRZ - one of the most negative values observed on oceanic basalts reported to date. However, we note that this sample had an extremely small quantity of $\left[\mathrm{N}_{2}\right]\left(0.88 \times 10^{-6} \mathrm{~cm}^{3} \mathrm{STP} / \mathrm{g}\right)$ and was not replicated thereby casting doubt on its reliability. Finally, we note that Mohapatra et al. (2009) analyzed two glass samples from the WRZ by stepped heating and obtained values of $-12.5 \%$ to $+16.5 \%$, which is well beyond the range observed here for the same region with vacuum crushing.

\subsection{Helium and argon abundances and isotopes}

In Figure 3, we plot He-isotopes versus $[\mathrm{He}]_{\mathrm{C}}$ (He concentration also corrected for air helium) of all the subglacial basalts listed in Table 1. Note that new He-isotopes results for the SIVZ (n=12), the WRZ (n=1) and the SNVZ (n=3) are given in Table S1, but only part of the new values from the SIVZ $(n=5)$ are plotted in Figure 3 as these samples were targeted for nitrogen isotopes. Helium concentrations range from 13.04 to $3447 \times 10^{-9} \mathrm{~cm}^{3} \mathrm{STP} / \mathrm{g}$ with only 1 sample having a concentration $<\sim 50 \times 10^{-9} \mathrm{~cm}^{3} \mathrm{STP} / \mathrm{g}$, in good agreement with the 
range of values previously reported for most Icelandic subglacial basalts (Condomines et al. 1983; Kurz et al. 1985; Poreda et al. 1986; Harrison et al. 1999; Dixon et al. 2000; Trieloff et al. 2000; Breddam \& Kurz, 2000; Dixon, 2003; Macpherson et al. 2005; Füri et al. 2010). The overall range of the samples targeted for nitrogen isotopes (see Table 1) in ${ }^{3} \mathrm{He} /{ }^{4} \mathrm{He}$ is from 8.5 to $25.7 \mathrm{R}_{\mathrm{A}}$, and is also comparable with previously reported values from Iceland (Füri et al., 2010 and ref. therein). Similar to what was noted by Füri et al., 2010, we see a clear distinction between different rift segments and emphasize four main points: (1) only samples from the NRZ overlap the DMM range $\left(8 \pm 1 R_{A}\right)$, but the NRZ also extends to higher values - notably, DMM-like values are predominantly found in the northern part of the NRZ, whereas higher values (up to $19.7 \mathrm{R}_{\mathrm{A}}$ ) occur towards central Iceland, (2) samples from the WRZ show a more restricted range of values from 12.5 to $21.1 \mathrm{R}_{\mathrm{A}}$. Excluding the highest value of $21.1 \mathrm{R}_{\mathrm{A}}$, the remaining WRZ samples all lie between 12.5 and $17.2 \mathrm{R}_{\mathrm{A}}$, (3) all samples from the ERZ display ${ }^{3} \mathrm{He} /{ }^{4} \mathrm{He}>18 \mathrm{R}_{\mathrm{A}}$, with a restricted range of values from 18.1 to $25.9 \mathrm{R}_{\mathrm{A}}$, and finally, (4) SIVZ samples, all display ${ }^{3} \mathrm{He} /{ }^{4} \mathrm{He}>18 \mathrm{R}_{\mathrm{A}}$ and reach values as high as $25.7 \mathrm{R}_{\mathrm{A}}$, at Príhyrningur, in good agreement with the ${ }^{3} \mathrm{He} /{ }^{4} \mathrm{He}$ ratio of $26.2 \mathrm{R}_{\mathrm{A}}$ obtained previously at this location (Kurz et al., 1985).

The total ${ }^{40} \mathrm{Ar}$ content, which represents a mixture of air-derived argon and intrinsic radiogenic argon (i.e., $\left[{ }^{40} \mathrm{Ar}^{*}\right]$ ), is corrected for the presence of atmospheric argon, assuming that all ${ }^{36} \mathrm{Ar}$ is atmosphere-derived, in the following manner:

$$
{ }^{40} \mathrm{Ar} *=\left[{ }^{36} \mathrm{Ar} m\right] \times\left[\left({ }^{40} \mathrm{Ar} /{ }^{36} \mathrm{Ar}\right)_{\mathrm{m}}-\left({ }^{40} \mathrm{Ar} /{ }^{36} \mathrm{Ar}\right)_{\text {air }}\right]
$$

where ${ }^{40} \mathrm{Ar} *$ is radiogenic argon, and ${ }^{36} \mathrm{Ar}$ m and $\left({ }^{40} \mathrm{Ar} /{ }^{36} \mathrm{Ar}\right)_{\mathrm{m}}$ are the measured values and $\left({ }^{40} \mathrm{Ar} /{ }^{36} \mathrm{Ar}\right)_{\text {air }}$ is the air ratio (=298.6; Lee et al., 2006), respectively. In Figure 4a, we plot ${ }^{40} \mathrm{Ar} /{ }^{36} \mathrm{Ar}$ ratios versus radiogenic ${ }^{40} \mathrm{Ar} *$ for the same samples as in Figure 2. The radiogenic 
294

295

296

297

298

299

300

301

302

303

304

305

306

307

308

309

310

311

312

313

314

Ar concentrations $\left[{ }^{40} \mathrm{Ar} *\right.$ ] vary from 0.1 to $1734 \times 10^{-9} \mathrm{~cm}^{3} \mathrm{STP} / \mathrm{g}$ with the highest values found at the MID-1, Miðfell/Dagmálafell (i.e., DICE) locality. This range of values is comparable to the range previously reported for oceanic basalts where $\left[{ }^{40} \mathrm{Ar} *\right]$ generally lies between $\sim 10^{-9}$ and $\sim 10^{-6} \mathrm{~cm}^{3} \mathrm{STP} / \mathrm{g}$ (e.g., Yamamoto and Burnard, 2005).

We note a positive correlation between $\left[{ }^{40} \mathrm{Ar} *\right]$ and $\left[\mathrm{N}_{2}\right]$ over several orders of magnitude (Figure 2a) - consistent with a coupling of $\mathrm{N}$ and radiogenic Ar trapped in vesicles of subglacial glasses (e.g., Marty, 1995).

Argon isotopes $\left({ }^{40} \mathrm{Ar} /{ }^{36} \mathrm{Ar}\right)$ show a narrow range of values from atmospheric-like values to 1334 . These values are both comparable to and/or lower than those reported previously for Iceland (air-like to 6500; Burnard et al. 1994; Harrison et al. 1999; Trieloff et al. 2000; Burnard and Harrison, 2005; Füri et al., 2010; Mukhopadhyay, 2012) but much lower than mantle source estimates for ridge basalts ( 5000 to 40,000; e.g., Burnard et al., 1997; Trieloff and Kunz, 2005). Notably, a significant number of samples ( $n=9$ ) have ${ }^{40} \mathrm{Ar} /{ }^{36} \mathrm{Ar}$ nearly identical to the isotopic composition of air (298.6; Lee et al. 2006).

In Figure 4b, we plot ${ }^{4} \mathrm{He} /{ }^{40} \mathrm{Ar} *$ ratios versus radiogenic ${ }^{40} \mathrm{Ar} *$. As noted above, many samples ( $\mathrm{n}=9$ ) have air-like ${ }^{40} \mathrm{Ar} /{ }^{36} \mathrm{Ar}$ ratio, precluding calculation of the ${ }^{4} \mathrm{He} /{ }^{40} \mathrm{Ar} *$ ratio. Other samples show a wide range in ${ }^{4} \mathrm{He} /{ }^{40} \mathrm{Ar} *$ ratios from 0.4 to 135 . A significant number of samples fall within the present and time-integrated theoretical ${ }^{4} \mathrm{He} /{ }^{40} \mathrm{Ar} *$ production ratio (P.R.) calculated for the upper-mantle (P.R. = 1.4 to 4.8; e.g., Porcelli \& Ballentine, 2002; Yamamoto and Burnard, 2005; Hanyu et al., 2011), whereas four samples display ${ }^{4} \mathrm{He} /{ }^{40} \mathrm{Ar} *$ ratios < 1.4. As demonstrated by Füri et al. (2010), parental melts of the Iceland plume have undergone significant depletion of helium relative to neon and argon - a process likely responsible for ${ }^{4} \mathrm{He} /{ }^{40} \mathrm{Ar} *$ ratios $<$ theoretical upper-mantle values observed in our dataset. We also note that samples with the highest ${ }^{4} \mathrm{He} /{ }^{40} \mathrm{Ar} *$ ratios are associated with low $\left[{ }^{40} \mathrm{Ar} *\right]$, likely due to preferential loss of ${ }^{40} \mathrm{Ar} *$ relative to ${ }^{4} \mathrm{He}$ during degassing. 


\section{Discussion}

321

322 Our aim is to discern primary $\delta^{15} \mathrm{~N}$ features of the Icelandic mantle source, and to assess the 323 role and extent of any secondary processes in masking primary mantle nitrogen features. In 324 section 5.1, we assess the entire $\mathrm{N}$ database to identify samples whose $\mathrm{N}$ systematics may

325 have been compromised by secondary processes. This approach allows us to identify unmodified samples and to then consider evidence for a recycled $\mathrm{N}$ component in the source region of Iceland lavas (sections 5.2 and 5.3). The nature and timing of recycling based upon other isotopic evidence is discussed in section 5.4.

\subsection{Integrity of data} to 1) air contamination, 2) degassing, and/or 3) shallow-level crustal contamination. In the following sections (5.1.1. to 5.1.5.), we adopt a step-by-step filtering protocol to test the integrity of individual samples, and to identify those that are best representative of the mantle source region.

\subsubsection{Air contamination and entrapment of air-derived components} adopted the following criteria to help recognize samples affected by air:

1. Air-like elemental ratios involving $\mathrm{N}_{2}$ : If $\mathrm{N}_{2} / \mathrm{Ar}$ values are $<\operatorname{air}(83)$, but $\geq$ airsaturated water $(\mathrm{ASW})\left(\right.$ e.g. $=38$; at $\left.0^{\circ} \mathrm{C}\right)$, they are suspect as they may be 
contaminated with air and/or ASW. In Figure 2c, we plot $\mathrm{N}_{2} / \mathrm{Ar}$ versus $\left[\mathrm{N}_{2}\right]$ to identify such samples. Iceland glasses have $\mathrm{N}_{2} / \mathrm{Ar}$ ratios between 85 and 425 (all have values greater than ASW), but we note that three samples (NES-1, NAL-600 and NAL-688) overlap with air when considering the maximum $10 \%$ analytical uncertainty. These three samples are omitted from further consideration.

2. Air-like ${ }^{40} \mathrm{Ar} /{ }^{36} \mathrm{Ar}$ ratios: In Figure 5a, we plot ${ }^{40} \mathrm{Ar} /{ }^{36} \mathrm{Ar}$ versus $\delta^{15} \mathrm{~N}$ values for the Iceland glasses and the MORB/OIB database (Marty and Humbert, 1997; Marty and Zimmerman, 1999; Marty and Dauphas, 2003a). Coupled $\delta^{15} \mathrm{~N}-{ }^{40} \mathrm{Ar} /{ }^{36} \mathrm{Ar}$ systematics of the Iceland glasses differ from both MORB and OIB as ${ }^{40} \mathrm{Ar} /{ }^{36} \mathrm{Ar}$ ratios do not exceed values significantly greater than $\sim 1000$ with only 4 samples having ${ }^{40} \mathrm{Ar} /{ }^{36} \mathrm{Ar}$ ratios $>500$. This indicates that a large component of argon in Icelandic glasses is airderived, consistent with prior studies (e.g., Burnard et al. 1994; Harrison et al. 1999; Trieloff et al. 2000; Burnard and Harrison, 2005; Füri et al., 2010; Mukhopadhyay, 2012). Whether a recycled argon component is responsible for such low ratios (e.g., Sarda et al., 1999; Holland and Ballentine, 2006) still remains an open question. We investigate coupled $\delta^{15} \mathrm{~N}-{ }^{40} \mathrm{Ar} /{ }^{36} \mathrm{Ar}$ systematics in more detail by focusing on samples with ${ }^{40} \mathrm{Ar} /{ }^{36} \mathrm{Ar}$ ratios $<330$ (Figure 5b). We note that two samples (NAL-281 and BHE-43) with air-like ${ }^{40} \mathrm{Ar} /{ }^{36} \mathrm{Ar}$ ratios overlap with air $\delta^{15} \mathrm{~N}$, and 7 others (NES-1, REY-1, NAL-356, NAL-500, A11, A18/ICE08R-12, TRÍ-2) display ${ }^{40} \mathrm{Ar} /{ }^{36} \mathrm{Ar}$ ratios comparable to air. Thus, we omit all 9 samples from further consideration as they have likely incorporated a large component of air, which has possibly compromised $\delta^{15} \mathrm{~N}$ values. 
Another important process capable of modifying intrinsic mantle volatile features is magmatic degassing (e.g., Cartigny et al., 2001). The relative noble gas abundance ratio $\left({ }^{4} \mathrm{He}^{40} \mathrm{Ar}^{*}\right)$ provides a powerful tool for modeling the extent of degassing (e.g., Matsuda and Marty, 1995) because He is much more soluble than $\mathrm{Ar}$ in basaltic magmas $\left(\mathrm{S}_{\mathrm{He}} / \mathrm{S}_{\mathrm{Ar}}=9.5\right.$; Jambon et al., 1986 where $S$ = solubility). Consequently, the residual medium (i.e., basaltic glass) should display ${ }^{4} \mathrm{He} /{ }^{40} \mathrm{Ar} *$ values that increase as degassing proceeds and volatiles are lost.

In Figure 6, we plot elemental ratios involving $\mathrm{N}_{2}$, i.e., (a) $\mathrm{N}_{2} /{ }^{3} \mathrm{He}$ and (b) $\mathrm{N}_{2} /{ }^{40} \mathrm{Ar} *$ versus ${ }^{4} \mathrm{He} /{ }^{40} \mathrm{Ar} *$. Estimates for the ${ }^{4} \mathrm{He} /{ }^{40} \mathrm{Ar}^{*}, \mathrm{~N}_{2} /{ }^{3} \mathrm{He}$ and $\mathrm{N}_{2} /{ }^{40} \mathrm{Ar} *$ ratios of the upper-mantle (DMM: 1.4 to $4.8 ; 3.76 \pm 1.17\left(\times 10^{6}\right) ; 138 \pm 65$, respectively: Marty and Humbert, 1997; Marty and Zimmermann, 1999; Hanyu et al., 2011) are indicated by a dark-yellow shaded region and also given in Table 2. In order to estimate a representative $\mathrm{N}_{2} /{ }^{40} \mathrm{Ar} *$ ratio of the DMM reservoir, we calculated and compiled $\mathrm{N}_{2} /{ }^{40} \mathrm{Ar} *$ ratios using N-Ar data reported by Marty and Zimmermann (1999) and Marty and Humbert (1997). By adopting the same filtering protocols (i.e., using only samples with ${ }^{40} \mathrm{Ar} /{ }^{36} \mathrm{Ar}>1000$ ), as described by Marty and Zimmermann (1999), and by only considering values with He isotope ratios that are within the canonical DMM range $8 \pm 1 \mathrm{R}_{\mathrm{A}}$, we obtained a $\mathrm{N}_{2} /{ }^{40} \mathrm{Ar}^{*}$ ratio of $138 \pm 65(\mathrm{n}=28: 2$ standard error; $2 \sigma / \mathrm{n}^{1 / 2}$, where $\mathrm{n}$ is the number of values) for the DMM. Finally, we calculate an average $\mathrm{N}_{2} /{ }^{40} \mathrm{Ar} *$ ratio for Icelandic subglacial basalts of $1.59 \pm 1.43\left(\times 10^{5}\right)(\mathrm{n}=26)$. This value is both considerably more heterogeneous and significantly higher than estimates for both the DMM and OIB reservoirs.

The Icelandic glasses have $\mathrm{N}_{2} /{ }^{3} \mathrm{He}$ ratios (Figure 6a) that span the range of DMM estimates and vary by well over two orders of magnitude, from $2.5 \times 10^{5}$ to $9.0 \times 10^{7}$. We model predicted degassing profiles and superimpose Fractional Equilibrium Degassing (FED) and Batch Equilibrium Degassing (BED) trajectories using solubility coefficients of 5.60 
$\left(\times 10^{-4}\right)$ for He; 6.14 for $\mathrm{Ar}\left(\times 10^{-5}\right)$, and $5.12\left(\times 10^{-5}\right)$ for $\mathrm{N}_{2}$ (units of $\mathrm{cm}^{3} \mathrm{STP} / \mathrm{g}$; Jambon et al., 1986; Cartigny et al., 2001). Additionally, we assume starting values between 1.4 and 4.8 for ${ }^{4} \mathrm{He}^{40} \mathrm{Ar}^{*}$ and $3.76 \pm 1.17\left(\times 10^{6}\right)$ for $\mathrm{N}_{2} /{ }^{3} \mathrm{He}$ (e.g., Marty and Zimmermann, 1999). Using ${ }^{4} \mathrm{He} /{ }^{40} \mathrm{Ar} *$ as an example, the FED trend is calculated using:

$$
\left({ }^{4} \mathrm{He} /{ }^{40} \mathrm{Ar} *\right)_{\mathrm{r}}=\left({ }^{4} \mathrm{He} /{ }^{40} \mathrm{Ar} *\right)_{0} \mathrm{f}_{\mathrm{He}}{ }^{[1-(\mathrm{SHe} / \mathrm{SAr})]}
$$

and the BED trend is calculated using:

$$
\left({ }^{4} \mathrm{He} /{ }^{40} \mathrm{Ar}^{*}\right)_{\mathrm{r}}=\left({ }^{4} \mathrm{He} /{ }^{40} \mathrm{Ar} *\right)_{0} \times\left[\left(\mathrm{S}_{\mathrm{He}} / \mathrm{S}_{\mathrm{Ar}}\right)+\left(1-\mathrm{S}_{\mathrm{He}} / \mathrm{S}_{\mathrm{Ar}}\right) \times \mathrm{f}_{\mathrm{He}}\right]
$$

where $\mathrm{f}_{\mathrm{He}}$ is the remaining fraction of $\mathrm{He}$ in the melt and $\mathrm{S}_{\mathrm{He}}$ and $\mathrm{S}_{\mathrm{Ar}}$ are the fractionation (solubility) factors for $\mathrm{He}$ and $\mathrm{Ar}$, respectively. The subscripts, $\mathrm{r}$ and 0 , refer to residual and original values, respectively.

Using this approach, a total of 10 remaining Icelandic samples fall close (within error) to trajectories defined by degassing trajectories for FED and/or BED (Figure 6a). With the exception of seven samples that have $\mathrm{N}_{2} /{ }^{3} \mathrm{He}>4.93\left(\times 10^{6}\right)$, all these samples display ${ }^{4} \mathrm{He}^{40} \mathrm{Ar}^{*}>10$ (dashed black line; Figure 6a). Thus, these samples likely record altered (modified) $\mathrm{N}_{2} /{ }^{3} \mathrm{He}$ ratios, which are not representative of source values, in contrast to samples that display high $\mathrm{N}_{2} /{ }^{3} \mathrm{He}$ and low ${ }^{4} \mathrm{He} /{ }^{40} \mathrm{Ar} *$ which may better represent original source values (see below). All other samples have ${ }^{4} \mathrm{He}^{40} \mathrm{Ar}^{*}<10$, suggesting only moderate (i.e., $<20 \%$ in all cases) amounts of degassing, and therefore are likely to have preserved starting values. However, in the case of Icelandic melts as a whole, we note that Füri et al., (2010) showed that samples with ${ }^{4} \mathrm{He} /{ }^{40} \mathrm{Ar} *$ ratios close to the mantle production values do not necessarily indicate that samples have been unaffected by degassing. Füri et al. (2010) 
showed that low ${ }^{4} \mathrm{He} /{ }^{40} \mathrm{Ar} *$ ratios can also be explained by open system equilibrium degassing of a melt that has been previously depleted in helium relative to argon by a primary mantle fractionation event. Thus an alternative explanation for the model presented in Figure 6a, involves ${ }^{4} \mathrm{He} /{ }^{40} \mathrm{Ar} *$ starting values significantly less than 1.4 . This scenario is indicated by the blue arrows extending to the left from the DMM field on Figure 6a. Indeed, a ${ }^{4} \mathrm{He} /{ }^{40} \mathrm{Ar} *$ starting value to 0.1 , for both FED and/or BED, provides a significantly better fit to the data in Figure 6a, indicating that the majority of samples (27 of 34) have $\mathrm{N}_{2} /{ }^{3} \mathrm{He}$ ratios that are likely to be unrepresentative of their source values.

The $\mathrm{N}_{2} /{ }^{40} \mathrm{Ar}^{*}$ values vary between 32.8 and $1.46 \times 10^{6}$, extending well beyond estimates for DMM (Figure 6b). Assuming a $\mathrm{N}_{2} /{ }^{40} \mathrm{Ar}^{*}$ starting value of $138 \pm 65$, none of the samples fall on the degassing trajectories. Due to the fact that nitrogen and argon have similar solubilities in basaltic melt, the FED trajectory is nearly horizontal, leading to virtually no change in the $\mathrm{N}_{2} /{ }^{40} \mathrm{Ar}^{*}$ value upon degassing. Significantly, this observation holds irrespective of the ${ }^{4} \mathrm{He} /{ }^{40} \mathrm{Ar} *$ starting values. Thus, magmatic degassing fails to explain the marked enrichment of $\mathrm{N}_{2}$ over ${ }^{40} \mathrm{Ar} *$ observed in Figure $6 \mathbf{b}$, and the high ratios cannot be produced by solubility controlled degassing.

Finally, we plot a possible binary mixing trajectory (in red in Figure 6b) between (i) a mantle component with low $\mathrm{N}_{2} /{ }^{40} \mathrm{Ar} *$ and ${ }^{4} \mathrm{He} /{ }^{40} \mathrm{Ar} *$ ratios, and (ii) a component with high $\mathrm{N}_{2} /{ }^{40} \mathrm{Ar} *$ and ${ }^{4} \mathrm{He} /{ }^{40} \mathrm{Ar} *$ ratios. Due to the fact that samples with ${ }^{4} \mathrm{He} /{ }^{40} \mathrm{Ar} *>10$ have lost a larger proportion of their initial volatile content, they become more susceptible to the addition of extraneous volatiles (e.g., crustal and/or atmospheric in origin). Thus, a possible explanation for the high $\mathrm{N}_{2} /{ }^{40} \mathrm{Ar} *$ ratios evident in Figure $6 \mathbf{b}$ (i.e., for most samples with $\left.{ }^{4} \mathrm{He} /{ }^{40} \mathrm{Ar} *>10\right)$ is admixture with a component characterised by high $\mathrm{N}_{2} /{ }^{40} \mathrm{Ar} *$. Barry et al. (2014) suggested that organic material embedded in crustal wall rocks could explain low $\delta$ ${ }^{13} \mathrm{C}\left(\mathrm{CO}_{2}\right)$ values in some basalt samples: we suggest that an organic contribution could also 
account for high $\mathrm{N}_{2} /{ }^{40} \mathrm{Ar} *$ values. However, admixture with such a component only becomes evident in samples that are degassed $\left({ }^{4} \mathrm{He} /{ }^{40} \mathrm{Ar} *>10\right)$. This possibility is further evaluated in section 5.1.4.

\subsubsection{Magmatic degassing and nitrogen isotope fractionation}

A primary observation commonly used to argue for isotopic fractionation of nitrogen during degassing (Javoy, 1997; Cartigny et al., 2001) is the fact that MORB vesicles, which represent out-gassed (i.e., exsolved) mantle nitrogen, mostly have negative $\delta^{15} \mathrm{~N}$ values (Javoy and Pineau, 1991; Marty and Humbert, 1997; Marty and Zimmermann, 1999), whereas the residual nitrogen, extracted by fusion, often has higher $\delta^{15} \mathrm{~N}$ values (e.g., Exley et al., 1986).

We caution that some of these values may be biased due to kinetic effects during gas extraction (Boyd et al., 1993; Pinti et al., 2007; Yokochi et al. 2009) and the use of N-reactive metals (e.g., Yokochi and Marty, 2006), casting doubt on this simple comparison. Indeed, evidence has been presented against $\mathrm{N}$ isotope fractionation during magma degassing based on a study of olivine and geothermal gases collected at the same locations which shows similar $\delta^{15} \mathrm{~N}$ values for both types of sampling media (Fischer et al., 2005) and consideration of coupled $\delta^{15} \mathrm{~N}-{ }^{4} \mathrm{He} /{ }^{40} \mathrm{Ar} *$ systematics in oceanic basalts (e.g., Marty and Dauphas, 2003b).

To test whether observed $\mathrm{N}$-isotope variations of the Iceland glasses result from degassing-induced modification of a common mantle source $\delta^{15} \mathrm{~N}$ value, we present a simple fractional equilibrium model of degassing (section 5.1.3.1). However, additional stable isotope fractionation models, such as i) species- (i.e., solubility-) (e.g., Mysen \& Fogel, 2010) and ii) diffusion- (i.e., kinetic-) (e.g., Yokochi et al., 2009; Pinti \& Hashizume, 2010; Roulleau et al., 2012) induced isotopic fractionation, have also been proposed as means of 
modifying nitrogen isotope characteristics: these are discussed in sections 5.1.3.2 and 5.1.3.3, respectively.

\subsubsection{Fractional Equilibrium Degassing (FED)}

To test whether observed $\mathrm{N}$-isotope variations of the Iceland glasses result from degassing-induced modification of a common mantle source value, we plot ${ }^{4} \mathrm{He} /{ }^{40} \mathrm{Ar} *$ versus $\delta^{15} \mathrm{~N}$ in Figure 7a. We adopt two end-members (DMM: -5\% (gray box)) and the mean Iceland value: $+1.35 \%$ o (pattern box: without sample A-35) in our model as there remain considerable uncertainties regarding the selection of a nitrogen mantle component for Iceland. Using a simple FED degassing model to test the possible effects of magmatic degassing, we note that the $\delta^{15} \mathrm{~N}$ value of the melt is related to the remaining fraction of $\mathrm{N}$ in the melt $\left(\mathrm{f}_{\mathrm{N}}\right)$ in the following manner:

$\delta^{15} \mathrm{~N}_{\text {melt }}=\delta^{15} \mathrm{~N}_{0}+\Delta_{\mathrm{i}} \times \ln \mathrm{f}_{\mathrm{N}}$

where

$$
\Delta_{\mathrm{i}}=\delta^{15} \mathrm{~N}_{\mathrm{ves}}-\delta^{15} \mathrm{~N}_{\text {melt }}
$$

Here, $\Delta_{\mathrm{i}}$ is the isotopic equilibrium fractionation factor of $\delta^{15} \mathrm{~N}$ between vesicles and melt, and we adopt a value of $-1.6 \%$ from Cartigny et al. (2001). It is important to note that the fractionation factor used here is based on observations of vesicles and the solid phases of basaltic glasses from the south-west Indian Ridge. Further experimental work of nitrogen isotope behavior during degassing is needed in order to confirm this value. 
Significantly, by adopting a mantle production ratio for ${ }^{4} \mathrm{He} /{ }^{40} \mathrm{Ar} *$, degassing can

494

495

496

497

498

499

500

501

502

503

504

505

506

507

508

509

510

511

512

513

514

515

516

517

explain only a small subset of the dataset plotted in Figure 7a, even when taking the associated uncertainty estimates of the DMM end-member into account. Thus, the data are largely inconsistent with degassing induced isotopic fractionation of nitrogen from a mantle source $\delta^{15} \mathrm{~N}$ value equal to DMM and/or the mean Iceland values of $+1.35 \%$. This observation agrees with previous studies of oceanic basalts (e.g., Marty and Humbert, 1997; Marty and Dauphas, 2003), which also suggest that nitrogen isotope variations are independent of degassing (e.g., Marty and Humbert, 1997).

However, adopting lower ${ }^{4} \mathrm{He} /{ }^{40} \mathrm{Ar} *$ starting values (as low as 0.1 ; solid blue arrows), provides a significantly better fit to the data (blue line; Figure 7a), consistent with the notion that degassing-induced modification may have affected primary mantle $\delta^{15} \mathrm{~N}$ values. Despite such low ${ }^{4} \mathrm{He} /{ }^{40} \mathrm{Ar} *$ starting values, seven samples fall to the right of degassing trajectory, which can only be resolved by adopting a higher $\delta^{15} \mathrm{~N}$ starting value (e.g., the mean Iceland value: $+1.35 \%$ ). Therefore, we conclude that adopting a lower ${ }^{4} \mathrm{He} /{ }^{40} \mathrm{Ar} *$ starting value for the Icelandic mantle (Füri et al., 2010) will lead to the conclusion that degassing could have a major effect on the measured $\delta^{15} \mathrm{~N}$ values. However, we also point out that Füri et al. (2010) raised some concerns regarding the credibility of models involving low ${ }^{4} \mathrm{He} /{ }^{40} \mathrm{Ar} *$ starting values in the Icelandic mantle, particularly as crystal-melt partition coefficients for noble gases still remain poorly defined, which highlights the need for future work on this interesting observation.

\subsubsection{Species-induced isotopic fractionation}

The speciation of $\mathrm{N}$ (e.g., as $\mathrm{N}_{2}$ and $\mathrm{NH}_{3}$; the two major nitrogen-bearing species) dissolved in silicate melts in molecular form and as structural complexes, respectively, may 
influence stable isotope fractionation during melting and crystallization at high pressures and temperatures (Mysen et al., 2008; Mysen \& Fogel, 2010). We note that nitrogen in fluids under upper mantle conditions (e.g., 30-35 kbar $=90-105 \mathrm{~km}$ ) is mostly in the form of $\mathrm{N}_{2}$, while in the deeper and more reduced parts of the upper mantle (beyond $60 \mathrm{kbar}=180 \mathrm{~km}$ ), $\mathrm{NH}_{3}$ is the dominant nitrogen species (Brandes et al., 1998; Li et al., 2013; Li and Keppler, 2014). Thus, any interpretation of the nitrogen isotope values of melts formed at depth in the upper mantle would have to take into account the fact that most of the nitrogen was present as $\mathrm{NH}_{3}$. However, the isotope fractionation factor $\left(\Delta_{\mathrm{i}}\right)$ of $\delta^{15} \mathrm{~N}$ between $\mathrm{NH}_{3}$ and $\mathrm{N}_{2}$ is about $-1 \%$ (i.e., $\Delta_{\mathrm{i}}=\delta^{15} \mathrm{~N}_{\mathrm{NH} 3}-\delta^{15} \mathrm{~N}_{\mathrm{N} 2}$ ) at $1200^{\circ} \mathrm{C}$ (Richet et al., 1977), so it is unlikely that even the complete decomposition of $\mathrm{NH}_{3}$ to $\mathrm{N}_{2}$ and $\mathrm{H}_{2}$ in the upper-mantle could explain the highly positive $\delta^{15} \mathrm{~N}$ values in Icelandic melts.

\subsubsection{Diffusion-induced isotopic fractionation} a result of more rapid diffusion of ${ }^{14} \mathrm{~N}$ relative to ${ }^{15} \mathrm{~N}$, some of the available models have been applied to an apparent concentration gradient between fluid inclusions in xenoliths and/or phenocrysts and their host magma (e.g., Yokochi et al., 2009; Roulleau et al., 2012). However, diffusion is driven by concentration gradients and given that basaltic glasses can be regarded as a relatively homogenous transport medium of $\mathrm{N}_{2}$, large concentration gradients are unlikely within the glass phase.

Nevertheless, diffusion of the lighter isotope $\left({ }^{14} \mathrm{~N}\right)$ across the glass-vesicle interface during vesiculation is a possible process capable of enriching ${ }^{15} \mathrm{~N}$ in the melt phase. In this case, vesicles will have lower $\delta^{15} \mathrm{~N}$ values relative to the initial $\delta^{15} \mathrm{~N}$ value of the melt prior to vesiculation. Although experimental confirmation of this behavior warrants further studies, 
we note that such a mechanism is highly dependent on the melt-vesicle equilibrium partitioning, i.e., how much of the initial $\mathrm{N}$ goes into the vesicles phase from the melt phase to establish the requisite concentration gradients. In this respect, we note that several studies (e.g., Marty et al., 1983; Jambon et al., 1986; Marty and Zimmermann, 1999) have shown that the partitioning of argon (and thus also nitrogen) between vesicles and melt generally follows Henry's law, and that for vesicularities relevant to MORB glasses, Ar (and N) should be predominantly found in the vesicle phase.

However, on the basis on available studies, we note that Marty and Zimmermann (1999) argued that additional nitrogen components evident in the melt phase, and released by heating (e.g., Exley et al., 1986), are unlikely to result from melt-vesicle equilibrium partitioning, but are reflective of a secondary contribution from externally-derived nitrogen. Thus, we deem diffusion-induced isotopic fractionation speculative at this stage but note that further experimental work is needed to validate this possibility.

\subsubsection{Contamination with volatiles from the Iceland crust and assimilation of organic} material

In this section, we assess whether observed co-variations between $\mathrm{N}$-isotopes and various elemental ratios can be explained by admixture with a high- $\delta{ }^{15} \mathrm{~N}$ component originating within the Icelandic crust. Some studies suggest that there is a considerable overlap between mantle $\delta^{15} \mathrm{~N}$ values and bulk $\delta^{15} \mathrm{~N}$ values of altered oceanic crust (AOC), i.e., $\delta^{15} \mathrm{~N}_{\mathrm{AOC}} \sim-5 \%$ (Li et al., 2007). Other studies (e.g., Halama et al., 2012) view AOC as having higher and more heterogeneous $\delta^{15} \mathrm{~N}$ with respect to DMM e.g., $\delta^{15} \mathrm{~N}=-1.2 . \pm 3.7 \%$. Thus, the range of Iceland $\delta^{15} \mathrm{~N}$ values could, in part, reflect assimilation of crustal material prior to or during eruption. We note that Busigny et al. (2005) demonstrated that basalts from Ocean 
Drilling Program Site 1256, located on the eastern flank of the East Pacific Rise, consistent with ophiolitic meta-gabbros from the western Alps (Busigny et al., 2011), showed a clear enrichment in nitrogen during the alteration process, with consistently positive $\delta^{15} \mathrm{~N}$ values (up to $+10 \%$ ). They speculated that nitrogen in altered basalts and gabbros occurs mainly as an ammonium ion $\left(\mathrm{NH}_{4}^{+}\right)$and is fixed in various secondary minerals (celadonite, $\mathrm{K}$ - and Nafeldspars, smectite, and possibly also $\mathrm{Cu}-\mathrm{N}$ compounds). These minerals represent typical secondary minerals that have been identified in altered sections of Iceland crust, either in drill-cuts (Mehegan et al., 1982) or within the Tertiary lava pile (e.g., Neuhoff et al., 1999; 2000).

Recently, Barry et al. (2014) postulated that assimilation of organic material, contained within altered Iceland crust, was an important process that generated $\delta^{13} \mathrm{C}$ values as low as $-25 \%$ in samples that had lost a large fraction of their initial carbon inventory via degassing. The organic material could result from hydrothermal circulation of organic material (Lang et al., 2006) and/or biological activity during mineralization (Thorseth et al., 1992; Furnes et al., 2001; Fisk et al., 2003). Marty and Humbert (1997) showed that many oceanic basalts with relatively low ${ }^{40} \mathrm{Ar} /{ }^{36} \mathrm{Ar}$ ratios $(<1000)$ seem to be associated with positive $\delta^{15} \mathrm{~N}$ values, and proposed that such values reflect contamination of melts by a shallow component enriched in ${ }^{15} \mathrm{~N}$. Therefore, there is substantial evidence favoring a predominantly positive $\delta^{15} \mathrm{~N}$ isotope signature associated with the Icelandic crust, making shallow level crustal contamination, at least in case of samples with ${ }^{4} \mathrm{He} /{ }^{40} \mathrm{Ar} *>10$, a viable process for explaining some of the positive $\delta^{15} \mathrm{~N}$ signatures in Icelandic subglacial basalts.

To test if samples with low volatile concentrations have experienced greater additions of a crustal nitrogen component, we plot $\mathrm{N}_{2} /{ }^{40} \mathrm{Ar}^{*}$ versus $\delta^{15} \mathrm{~N}$ (Figure 7b). Estimates for DMM (138 \pm 65 and $-5 \pm 2 \%$, respectively) are indicated by the gray shaded area. With the exception of two samples, all samples have $\mathrm{N}_{2} /{ }^{40} \mathrm{Ar}^{*}>1000$ (horizontal dashed line). 
593 Significantly, there is not a clear correlation between $\mathrm{N}_{2} /{ }^{40} \mathrm{Ar} *$ and $\delta^{15} \mathrm{~N}$, and no evidence that 594 positive $\delta^{15} \mathrm{~N}$ signatures are accompanied by high $\mathrm{N}_{2} /{ }^{40} \mathrm{Ar} *$ ratios. Therefore, we conclude

595

596

597

598

599

600

601

602

603

604

605

606

607

608

609

610

611

612

613

614

615

616

617

that the intrinsic mantle nitrogen component has not been modified by the addition of extraneous nitrogen derived from the crust.

\subsubsection{Summary}

In identifying samples that are likely representative of the Iceland mantle source, we considered coupled $\delta^{15} \mathrm{~N}-{ }^{40} \mathrm{Ar} /{ }^{36} \mathrm{Ar}$ systematics, and identified a total of 9 samples that have experienced sufficient modification by air-contamination that they have not retained primary source features (section 5.1.1.). Possible degassing-induced modifications of both elemental (section 5.1.2.) and isotopic (5.1.3.) primary source features are highly dependent on presumed starting ${ }^{4} \mathrm{He} /{ }^{40} \mathrm{Ar} *$ ratios. For example, adopting ${ }^{4} \mathrm{He} /{ }^{40} \mathrm{Ar} *$ production ratios identical to DMM, degassing appears to have a minor effect only on primary mantle $\mathrm{N}_{2} /{ }^{3} \mathrm{He}$ and $\delta^{15} \mathrm{~N}$ values, and degassing-induced modifications only become evident in highly degassed samples (with ${ }^{4} \mathrm{He} /{ }^{40} \mathrm{Ar} *>10$ ).

However, adopting a lower ${ }^{4} \mathrm{He} /{ }^{40} \mathrm{Ar} *$ starting value, as argued by Füri et al. (2010) to be the case for the Icelandic mantle, leads to the conclusion that degassing could have a major effect on both $\mathrm{N}_{2} /{ }^{3} \mathrm{He}$ and $\delta^{15} \mathrm{~N}$ values. Irrespective of the ${ }^{4} \mathrm{He} /{ }^{40} \mathrm{Ar} *$ starting values, no such effect is apparent in the $\mathrm{N}_{2} /{ }^{40} \mathrm{Ar} *$ ratios. Finally, we found both $\mathrm{N}_{2} /{ }^{40} \mathrm{Ar} *$ ratios and $\delta^{15} \mathrm{~N}$ values to be unaffected by crustal contamination (section 5.1.4.), but the effect may become evident in samples with ${ }^{4} \mathrm{He} /{ }^{40} \mathrm{Ar} *$ ratios $>10$. Although our study highlights the need for further consideration of a low ${ }^{4} \mathrm{He} /{ }^{40} \mathrm{Ar} *$ mantle beneath Iceland, we conclude that a total of 22 samples (see samples labeled with $*$ in Table 1) with ${ }^{4} \mathrm{He} /{ }^{40} \mathrm{Ar}^{*}<10$ have experienced, at most, moderate $(<20 \%)$ degrees of degassing. These samples are likely to have preserved 
their intrinsic nitrogen elemental and isotope characteristics that are representative of the Icelandic mantle.

\subsection{He-N-Ar relationships: evidence for recycled nitrogen in the Iceland mantle source}

In this section, we investigate coupled $\mathrm{He}-\mathrm{N}-\mathrm{Ar}$ elemental and isotope systematics in order to assess whether the ${ }^{15} \mathrm{~N}$-enriched crustal component is integrated into the Iceland mantle source, and thus possibly provides information on the nature of recycled material from the deep-mantle. In Figure 8a, we plot $\mathrm{N}_{2} /{ }^{3} \mathrm{He}$ versus $\delta^{15} \mathrm{~N}$ values (only for samples with $\left.{ }^{4} \mathrm{He} /{ }^{40} \mathrm{Ar} *<10\right)$. We superimpose end-member compositions for DMM $\left(3.76 \pm 1.17 \times 10^{6} ;-5\right.$ $\pm 2 \%$ : Marty and Zimmerman, 1999; Marty and Dauphas, 2003a) and a hybrid Iceland mantle plume source that has incorporated a heterogeneous section of recycled crustal material $(1 \pm 6$ $\times 10^{10} ;+3 \pm 3 \%$ o: e.g., Sano et al., 1998; Marty and Dauphas, 2003) that dominates the nitrogen budget of the plume end-member (see Table 2). We make the assumption that the recycled crustal material has heterogeneous $\delta^{15} \mathrm{~N}$ values that vary between $+0 \%$ and $+6 \%$ and thus incorporates $\delta^{15} \mathrm{~N}$ values typical of the subducting slab, i.e., (i) modern organic sedimentary nitrogen $(+7 \pm 3 \%$ : Peters et al. 1978; Sano et al., 1998; Sano et al., 2001; Halama et al., 2014), (ii) subduction-related metasediments (+3.2 $\pm 2.1 \%$; Halama et al., 2014), (iii) metamorphosed oceanic crust (+4.5 $\pm 2.1 \%$; Halama et al., 2010; 2014), in addition to (iv) values proposed to characterize the recycled component evident at many OIB localities $(+3 \pm 2 \%$; Marty \& Dauphas, 2003a).

Irrespective of the uncertainty associated with the DMM value $\left(3.76 \pm 1.17 \times 10^{6} ;-5 \pm\right.$ 2\%o), binary mixing between DMM and the hybrid Iceland mantle plume (dashed gray lines) is only capable of explaining a small subset of samples plotted in Figure 8a. Rather, binary mixing, involving a low $\delta^{15} \mathrm{~N}$ end-member with $\mathrm{N}_{2} /{ }^{3} \mathrm{He} \sim 1 \times 10^{6}$ (Depleted-DMM), similar to 
643

644

645

646

647

648

649

650

651

652

653

654

655

656

657

658

659

660

661

662

663

664

665

666

667

the low ${ }^{4} \mathrm{He} /{ }^{40} \mathrm{Ar} *$ component evident in the Icelandic mantle (see section 5.1.2), appears to provide a better fit as it overlaps with a larger subset of samples. Two samples from the WRZ require an even lower $\mathrm{N}_{2} /{ }^{3} \mathrm{He}$ ratio (Ultra Depleted-DMM: $\sim 1 \times 10^{5}$ ) in the low $\delta^{15} \mathrm{~N}$ endmember. Significantly, irrespective of the absolute $\mathrm{N}_{2} /{ }^{3} \mathrm{He}$ value of the low $\delta^{15} \mathrm{~N}$ end-member, the data are consistent with a binary mixing scenario which involves a component that has (i) very high $\mathrm{N}_{2} /{ }^{3} \mathrm{He}$ ratios $\left(>1 \times 10^{8}\right)$ and (ii) predominantly positive $\delta^{15} \mathrm{~N}$ values. Such a component is similar to recycled $\mathrm{N}$ from modern subducted sedimentary material and metamorphosed oceanic crust (e.g., Sano et al., 1998; Marty \& Dauphas, 2003a; Halama et al., 2010; 2012).

In Figure 8b, we plot $\mathrm{N}_{2} /{ }^{40} \mathrm{Ar} *$ versus $\delta^{15} \mathrm{~N}$ of the same samples as in Figure 8a. Again, we superimpose two possible end-member compositions for DMM $(138 \pm 65 ;-5 \pm$ 2\%: Marty and Zimmerman, 1999; Marty and Dauphas, 2003a) and a hybrid Iceland plume source $\left(5 \pm 5 \times 10^{6} ;+3 \pm 3 \%\right.$ ). Note that the $\mathrm{N}_{2} /{ }^{40} \mathrm{Ar}^{*}$ value adopted for the hybrid Iceland plume component is somewhat higher than the highest $\mathrm{N}_{2} / \mathrm{Ar}$ (total $\mathrm{Ar}$ ) ratio of 21,000 reported for oceanic sediment (e.g., Matsuo et al., 1978). This is because oceanic sediments are likely to contain air-derived argon that acts to lower $\mathrm{N}_{2} / \mathrm{Ar}$. The $\delta^{15} \mathrm{~N}-\mathrm{N}_{2} /{ }^{40} \mathrm{Ar} *$ systematics of the Icelandic subglacial basalts are consistent with binary mixing between DMM and a hybrid Iceland mantle plume source. We note that compared to the $\delta^{15} \mathrm{~N}-\mathrm{N}_{2} /{ }^{3} \mathrm{He}$ systematics (Figure 8a), the DMM end-member provides a significantly better fit to the calculated mixing trajectories, with only two samples falling slightly off the binary mixing trajectory.

In general, therefore, the $\delta^{15} \mathrm{~N}-\mathrm{N}_{2} /{ }^{3} \mathrm{He}$ data show more scatter relative to the $\delta^{15} \mathrm{~N}$ $\mathrm{N}_{2} /{ }^{40} \mathrm{Ar} *$ data and the need for variable mantle (DMM-like) end-members is more problematic for the former. This observation can be explained by taking into account the fact that $\mathrm{He}$ is more readily fractionated from $\mathrm{N}_{2}$ than $\mathrm{N}_{2}$ from $\mathrm{Ar}$, and modifications of original 
668

669

670

671

672

673

674

675

676

677

678

679

680

681

682

683

684

685

686

687

688

689

690

691

values due to deep-level fractionation event(s), because of different partitioning behavior of $\mathrm{He}$ and $\mathrm{N}_{2}$ during melting and/or solubility controlled fractionation, (e.g., Moreira \& Sarda, 2000; Sarda \& Moreira, 2002; Füri et al., 2010). This is particularly relevant as it

demonstrates that measured $\mathrm{N}_{2} /{ }^{3} \mathrm{He}$ cannot be used to infer $\mathrm{N}_{2}$ fluxes directly by comparison with ${ }^{3} \mathrm{He}$, which is a common method adopted for $\mathrm{CO}_{2}$ (e.g., Barry et al., 2014). However, Figure 8b illustrates the robustness of the $\mathrm{N}_{2} /{ }^{40} \mathrm{Ar} *$ ratio to constrain mantle end-members. In Figure 9, we plot helium isotopes $\left({ }^{3} \mathrm{He} /{ }^{4} \mathrm{He}\right)$ versus $\delta^{15} \mathrm{~N}$ values to test possible relationships between high ${ }^{3} \mathrm{He} /{ }^{4} \mathrm{He}$ mantle material in the Iceland plume and $\delta^{15} \mathrm{~N}$ values. For a regional comparison, we include seven samples from the Reykjanes Ridge with $\delta^{15} \mathrm{~N}$ reported by Barry et al. (2012) and helium data by Hilton et al. (2000). All samples display ${ }^{40} \mathrm{Ar} /{ }^{36} \mathrm{Ar}$ ratios significantly higher than air, 6 out of 7 samples also have ${ }^{4} \mathrm{He} /{ }^{40} \mathrm{Ar} *$ ratios < 10 (de Leeuw, 2007). We adopt the end-member components listed in Table 2 for DMM and a hybrid Iceland plume assuming that it has entrained a recycled crustal component with $\delta^{15} \mathrm{~N}$ values of $+3 \pm 3 \%$.

There are two notable features in Figure 9. First, a binary mixing model (gray mixing lines), which takes the uncertainty associated with each end-member into account, between DMM and a hybrid Iceland plume readily explains the coupled $\delta^{15} \mathrm{~N}-{ }^{3} \mathrm{He} /{ }^{4} \mathrm{He}$ systematics of 12 out of 30 samples. The relative N/He ratios between plume and DMM components are expressed as r-values (where $\left.\mathrm{r}=(\mathrm{N} / \mathrm{He})_{\mathrm{PLUME}} /(\mathrm{N} / \mathrm{He})_{\mathrm{DMM}}\right)$, with an $\mathrm{r}$-value $=1$ implying identical N/He ratios in each end-member. Second, 18 out 30 samples, are inconsistent with rvalues $=1$ in the mixing model: rather concave upwards trajectories (up to $r=20$ ) imply that the plume end-member is characterized by a marked enrichment in its $\mathrm{N} / \mathrm{He}$ ratio relative to the DMM end-member consistent with either enrichment of nitrogen and/or depletion of helium in the plume source. 
Significantly, r-values $>1$ indicate that the high ${ }^{3} \mathrm{He} /{ }^{4} \mathrm{He}$ signature may be coupled with a high $\delta^{15} \mathrm{~N}$ end-member that has either i) lost He before mixing with the DMM endmember, similar to the two-step model of He depletion followed by open-system degassing developed by Füri et al. (2010), and/or ii) excess $\mathrm{N}_{2}$. In either case, the high $\delta^{15} \mathrm{~N}$ end-member needed to explain these mixing relationships suggests the presence of recycled $\mathrm{N}$ component(s) integrated into and/or entrained by the Iceland plume source.

\subsection{Origin of high $\mathrm{N}_{2}{ }^{A 0} \mathrm{Ar} *$ ratios in the Iceland mantle source}

A key observation of the present dataset is the fact that $\mathrm{N}_{2} /{ }^{40} \mathrm{Ar}^{*}$ ratios in Icelandic subglacial basalts are not only considerably more heterogeneous (range between 248 and 1.46 $\times 10^{6}$, with a mean of $1.59 \pm 1.43 \times 10^{5}$ : see Section 5.1 .2 .), but also significantly higher, than DMM mean (138 \pm 65) and OIB mean (137 \pm 24$)$ (Marty and Humbert, 1997; Marty and Zimmermann 1999; Marty \& Dauphas, 2003a and Section 5.1.2.). Recent experimental work has highlighted the fact that high $\mathrm{N}_{2} /{ }^{40} \mathrm{Ar} *$ ratios in the Earth's mantle may result from physiochemical processes in the deep Earth such as:

\section{(i) The complex speciation of nitrogen in melts under high pressure and the possible} presence of nitrogen species that are more compatible than Ar (Roskosz et al. 2006): For example, nitrides are probably the main speciation of nitrogen under very reducing conditions, whereas nitrosyl (NO) dominates under more oxidizing conditions (Roskosz et al. 2006). Additionally, recent solubility studies of nitrogen in upper-mantle minerals suggest that the reduced lower part of the upper mantle has a large nitrogen storage capacity, and that, under such reduced conditions, a significant fraction of nitrogen may still be retained following melt extraction (Li et al., 2013; 
Johnson and Goldblatt, 2015). Extensive melt extraction, from the reduced uppermantle under Iceland, would thus generate higher $\mathrm{N}_{2} /{ }^{40} \mathrm{Ar}^{*}$ ratios relative to DMM and OIB. However, in contrast to observations from other OIBs that display much lower $\mathrm{N}_{2} /{ }^{40} \mathrm{Ar} *$ ratios (see Section 5.1.2), such high ratios should also be present at other oceanic hotspots. Unless melting dynamics under Iceland are notably different in comparison with other oceanic hotspots, it seems unlikely that mantle-melting involving nitrogen components more compatible than Ar in the upper mantle can explain high $\mathrm{N}_{2} /{ }^{40} \mathrm{Ar}^{*}$ ratios.

(ii) Contributions from nitrogen in the core to the nitrogen inventory of the lower-mantle: The notion is based on the observation that nitrogen is slightly-to-moderately siderophile at high pressure and temperature, whereas Ar is not, and recent metal/silicate nitrogen partitioning experiments that suggest some nitrogen can be sequestrated into the core (Roskosz et al. 2013). If trapped nitrogen interacts with the lower-mantle (e.g., via diffusion as proposed by Hayden \& Watson, 2007), it can become entrained by an uprising mantle plume, leading to a high $\mathrm{N}_{2} /{ }^{40} \mathrm{Ar} *$ relative to the DMM. However, direct core contributions to Icelandic magmatism remains unlikely at present given evidence of near uniform ${ }^{186} \mathrm{Os} /{ }^{188} \mathrm{Os}$ ratio in Icelandic picrites (Brandon et al., 2007). Instead, observed ${ }^{187} \mathrm{Os} /{ }^{188}$ Os are best explained by incorporation of recycled crust into the Icelandic mantle (Brandon et al., 2007; Sobolev et al., 2008).

Significantly, low $\mathrm{N}_{2} /{ }^{40} \mathrm{Ar} *$ ratios $(<\mathrm{DMM})$ that characterize many E-MORB and OIB, have led to suggestions that link $\mathrm{N}_{2} /{ }^{40} \mathrm{Ar} *$ ratios to extreme potassium recycling and a mantle residence time of recycled material and subsequent radiogenic in-growth of ${ }^{40} \mathrm{Ar}$ on a $10^{8}$ $10^{9}$ year timescale (Marty and Humbert, 1997; Nishio et al., 1999; Marty and Zimmermann, 
1999). This age is largely consistent with the enrichment of radiogenic isotopes in E-MORB and OIB and suggestions of the involvement of recycled components in the source of such regions (e.g., Hofmann and White, 1982). In the case of Iceland, extreme $\mathrm{N}_{2} /{ }^{40} \mathrm{Ar} *$, relative to other OIB localities, suggest that the recycled component in Iceland should be significantly younger $\left(<\right.$ few $\left.10^{8}\right)$ than recycled components elsewhere.

Thus, high $\mathrm{N}_{2} /{ }^{40} \mathrm{Ar} *$ values, in addition to positive $\delta^{15} \mathrm{~N}$ values that are evidently integrated into the Iceland plume source, have important implications for constraining the age of recycled components. Marty and Dauphas (2003a) have previously advanced a hypothesis invoking recycling of post-Archean material from the surface into the deep mantle, implying that nitrogen in mantle plumes originates from $\mathrm{N}_{2}$-rich sedimentary material. A key argument in their discussion was the observation that the $\mathrm{N}$ isotopic composition of OIB resembles that of organic matter found in post-Archean sediments, metamorphic rocks, and subductionrelated volcanic rocks. Although a recent compilation of Precambrian sedimentary nitrogen isotope compositions identified positive $\delta^{15} \mathrm{~N}$ values as far back as the Eoarchean (e.g., Thomazo \& Papineau, 2013), the combination of extreme $\mathrm{N}_{2} /{ }^{40} \mathrm{Ar}^{*}$ and positive $\delta^{15} \mathrm{~N}$ values in the Iceland mantle source, which are associated with high ${ }^{3} \mathrm{He} /{ }^{4} \mathrm{He}$ ratios (Figure 9), are thus consistent with deep subduction of post-Archean sediments.

\subsection{Recycling of Phanerozoic oceanic crust: constraints from other isotope systems}

$$
\text { Further constraints on the age of the recycled crustal material entrained by the }
$$
Icelandic mantle plume are also available by considering radiogenic isotopes. On the basis of trace elements and radiogenic isotopes, Chauvel and Hemond (2000), and Kokfelt et al (2006), proposed that the full compositional spectrum of Icelandic melts could be generated through recycling of a complete section of oceanic crust entrained into the Icelandic plume. 
Skovgaard et al. (2001) presented coupled O-Os isotope data to argue for the presence of recycled oceanic lithosphere in the source of lavas from Theistareykir (NRZ), and ocean crust recycling was also favored in the studies of Hanan and Schilling (1997), Hanan et al., (2000), Kempton et al. (2000), Fitton et al. (2003), Stracke et al. (2003), McKenzie et al., (2004), Macpherson et al. (2005) and Magna et al., (2010).

Thirlwall et al. (2004) demonstrated that negative $\Delta^{207} \mathrm{~Pb}$ values (deviation of ${ }^{207} \mathrm{~Pb} /{ }^{204} \mathrm{~Pb}$ for a given ${ }^{206} \mathrm{~Pb} /{ }^{204} \mathrm{~Pb}$ relative to the Northern Hemisphere Reference Line) associated with DMM-like compositions, characterize many Icelandic lavas, and proposed that such signatures are likely to have formed in a mantle component with higher $\mathrm{U} / \mathrm{Pb}$ ratio relative to the DMM at a time as recent as $\sim 170 \mathrm{Ma}$ ago but not earlier than $\sim 450 \mathrm{Ma}$ ago. Iceland is thus a type example of a young HIMU (high- $\mu$ ) mantle source (e.g., Thirlwall, 1995; 1997). Negative $\Delta^{207} \mathrm{~Pb}$ in Iceland lavas therefore suggest involvement of Palaeozoic oceanic crust, which is initially heterogeneous in $\mathrm{Pb}$ isotopes. The negative $\Delta^{207} \mathrm{~Pb}$ signal appears to encompass the entire region between $56^{\circ} \mathrm{N}$ and $70^{\circ} \mathrm{N}$ (Thirlwall et al., 2004), which is associated with elevated ${ }^{3} \mathrm{He} /{ }^{4} \mathrm{He}$ ratios (e.g., Füri et al., 2010) and, to some extent, low $\delta^{18} \mathrm{O}$ values (e.g., Gautason \&Muehlenbachs, 1998; Macpherson et al., 2005; Thirlwall et al., 2006). Thus, melts in this whole region of the North-Atlantic are predominantly derived from a mantle plume source that has incorporated relatively young (i.e., Palaeozoic) recycled oceanic crust and primordial ${ }^{3} \mathrm{He}$ from the deep mantle (Thirlwall et al., 2004). Peate et al., (2010) and Manning and Thirlwall (2014) have also shown that lavas from the Öræfajökull volcano in southern Iceland display positive $\Delta^{207} \mathrm{~Pb}$ that are consistent with small $(\sim 0.5 \%)$ contributions of recycled sediment in the mantle source under this volcano. In contrast, Kokfelt et al. (2006) proposed that recycled lithosphere with an older age $(\sim 1.5 \mathrm{Ga})$ could account for the $\mathrm{Pb}$ isotopic signatures of neovolcanic zone lavas of Iceland consistent with Os isotope studies, which suggest a recycled component of $<2 \mathrm{Ga}$, but 
possibly as young as $750 \mathrm{Ma}$ (Brandon et al., 2007; Sobolev et al., 2008). We note, however, the Os-studies have so far been mainly directed at two localities - the Reykjanes Peninsula and Theistareykir - and both show the most depleted (unradiogenic) Pb isotope compositions (e.g., Stracke et al., 2003; Thirlwall et al., 2004) consistent with derivation from the oldest part of the Iceland mantle source. In addition, Re-Os decay model ages are highly dependent on the initial Re/Os ratio of the subducted crust, which remains poorly constrained due to the high mobility of Re during subduction (e.g., Sun et al., 2004). In any case, radiogenic isotopes constrain the age of the recycled component incorporated by the Iceland mantle plume to be (significantly) less than $2 \mathrm{Ga}$, and possibly as young as $170 \mathrm{Ma}$, likely pointing to a Phanerozoic age (<541 Ma).

The extreme $\mathrm{N}_{2} /{ }^{40} \mathrm{Ar} *$ ratios in the Iceland mantle source relative to other OIBs are consistent with the age of the recycled component being significantly younger than recycled component sampled by other oceanic hotspots. Thus, we favor a Phanerozoic age of the recycled component, but note that the $\mathrm{Pb}$ isotope models presented by Thirlwall et al. (2004) may possibly constrain the age of this component further to the Palaeozoic era (252 to 541 Ma). In this respect, we point out that Harlou et al. (2009) reported highly radiogenic ${ }^{87} \mathrm{Sr} /{ }^{86} \mathrm{Sr}$ ratios $(\sim 0.708)$ in primitive ankaramites from NW-Iceland. Such radiogenic ${ }^{87} \mathrm{Sr} /{ }^{86} \mathrm{Sr}$ ratios have also been measured in Hawaiian ultra-depleted melt inclusions and used to advocate for the recycling of (young) Phanerozoic oceanic crust in the Hawaiian mantle plume (Sobolev et al., 2011). Such a short timescale for the Hawaiian and Iceland mantle plumes, predates previous source differentiation estimates for deep mantle plumes (e.g., McKenzie et al., 2004), and indicates considerably faster mantle circulation timescales, assuming that the subducted crust was delivered to the core-mantle boundary and recycled back to the surface via mantle upwelling. 
Finally, we note that a major tectonic event, which inevitably affected the upper-

mantle structure in the North-Atlantic during the Phanerozoic, was the closure of the Iapetus Ocean by convergence of the protocontinents of Laurentia, Baltica, and Avalonia, between 500 to 400 Ma (e.g., Barker \& Geyer, 1984; Bott, 1985; Soper et al., 1992). Evidence for the presence of this ancient subduction system is present today in the Caledonian collision zone (i.e., suture) that represents a broad zone of compression found in east Greenland, Scandinavia, Britain, Europe, and Newfoundland (Barker \& Geyer, 1984; Trosvik et al., 2015). It is thus quite possible that recycled crustal components evident in Icelandic melts are mostly confined to the upper-mantle. In this respect, the coupled $\delta^{15} \mathrm{~N}-{ }^{3} \mathrm{He} /{ }^{4} \mathrm{He}$ systematics would favor a model involving remobilization of the entrained upper-mantle material by an uprising Iceland mantle plume whose roots may be as deep as the core-mantle boundary (e.g., Helmberger et al., 1997; He et al., 2015).

\section{Conclusions}

Based on the N-Ar-He relative abundance and isotope systematics of subglacial basaltic glasses, we emphasize the following key observations:

$\square$ Nitrogen isotopes in subglacial basalts from Iceland span a large range of $\delta^{15} \mathrm{~N}$ values from -2.91 to $+11.96 \%$ that are generally more positive than DMM values and largely overlap with $\delta^{15} \mathrm{~N}$ values obtained from OIB worldwide.

$\square$ Coupled isotope and relative abundance systematics suggest that a recycled nitrogen component is present in the Icelandic mantle

We propose that the Iceland mantle plume has incorporated a section of subducted oceanic crust, whose age may possibly be as young as the Phanerozoic, as constrained by the combination of positive $\delta^{15} \mathrm{~N}$ values, radiogenic isotopes (e.g., $\mathrm{Pb}$ ), and very 
high $\mathrm{N}_{2} /{ }^{40} \mathrm{Ar}^{*}$ relative to other OIB. This implies a relatively short mantle-residence time for this recycled material.

\section{Acknowledgements}

We gratefully acknowledge NSF grants EAR-0439122 and EAR-0537618 for field work in Iceland and ensuing support of the doctoral dissertations of EF, PHB and SAH, and EAR0651097 for upgrade of the VG5400 mass spectrometer for N-isotope work. Samples came from the extensive collections of KG, supplemented by field collections (this work and from Guðrún Sverrisdóttir from the Hekla region). We are grateful to Níels Óskarsson for discussions on the occasion of his retirement. We also thank Ralf Halama and Aurélia Colin for constructive comments which helped to improve the presentation of this work.

Figure 1. Map of Iceland showing sampling locations and the neovolcanic zones with the oldest part of the island shown in blue. These include the axial rift zones: the Western (WRZ), Eastern (ERZ), and Northern rift zones (NRZ), in addition to the off-axis volcanic zones: the South Iceland Volcanic Zone (SIVZ), the Snæfellsnes Volcanic Zone (SNVZ) and the Öræfajökull Volcanic Zone (OVZ). From Jóhannesson and Sæmundsson (1998).

Figure 2. Plot of (a) ${ }^{40} \mathrm{Ar}^{*}$, (b) $\delta^{15} \mathrm{~N}$ and (c) $\mathrm{N}_{2} / \mathrm{Ar}$ versus $\left[\mathrm{N}_{2}\right]$ concentrations for Icelandic basalts. In (a-c), we also plot data from Mid-Ocean Ridge basalts (MORB) and Oceanic Island Basalts (OIB) that where obtained by in vacuo crushing (Marty and Humbert, 1997; Marty and Zimmerman, 1999; Marty and Dauphas, 2003a). In b) we do not plot the following samples due their high blank contribution: OLF-1 (41\%), MAE-1 (30\%), KVIH-1 (87\%), A13/ICE08R-09 (47\%), A32 (41\%): therefore, $n=38$ Iceland samples are shown. Air is 
indicated with the dashed black line and the mean $\delta^{15} \mathrm{~N}$ value of the depleted MORB mantle (DMM) reservoir $(-5 \pm 2 \%)$ with the solid gray line together with the associated uncertainty with dashed gray lines. In (c) the $\mathrm{N}_{2} / \mathrm{Ar}$ values of air (83) and air-saturated water (ASW) (38; at $0^{\circ} \mathrm{C}$ ) are indicated by dashed gray lines. Significantly, most samples have $\mathrm{N}_{2} / \mathrm{Ar}$ ratios above the air value, indicating that air contamination does not overwhelm samples.

Figure 3. He-isotope ratios (reported as $\mathrm{R}_{\mathrm{C}} / \mathrm{R}_{\mathrm{A}}$ : where $\mathrm{R}_{\mathrm{A}}=$ air ${ }^{3} \mathrm{He} /{ }^{4} \mathrm{He}$ ) versus $[\mathrm{He}]_{\mathrm{C}}$ corrected for the presence of atmospheric helium of all subgalcial basalts targeted for nitrogen in this study. Note that data from the SIVZ $(n=5)$ can be found in Table S1, whereas all other data are from Füri et al. (2010). The canonical DMM range of $8 \pm 1 \mathrm{R}_{\mathrm{A}}$ is from Graham (2002).

Figure 4. (a) Argon isotope ratios $\left({ }^{40} \mathrm{Ar} /{ }^{36} \mathrm{Ar}\right)$ and (b) ${ }^{4} \mathrm{He} /{ }^{40} \mathrm{Ar} *$ ratios versus radiogenic ${ }^{40} \mathrm{Ar} *$. Also indicated are the present (1.4) and time-integrated (4.8) theoretical ${ }^{4} \mathrm{He} /{ }^{40} \mathrm{Ar} *$ Production Ratios calculated for the upper-mantle (Porcelli \& Ballentine, 2002; Yamamoto and Burnard, 2005; Hanyu et al., 2011). The air ${ }^{40} \mathrm{Ar} /{ }^{36} \mathrm{Ar}$ value is 298.6 from Lee et al. (2006).

Figure 5. Argon isotope ratios $\left({ }^{40} \mathrm{Ar} /{ }^{36} \mathrm{Ar}\right)$ versus $\delta^{15} \mathrm{~N}$ values of Iceland glasses. In (a), MORB and OIB glasses are shown for comparison (from Marty and Humbert, 1997; Marty and Zimmerman, 1999; Marty and Dauphas, 2003a). The isotopic composition of air $\left(\delta^{15} \mathrm{~N}\right.$ $=0 \%$ and $\left.{ }^{40} \mathrm{Ar} /{ }^{36} \mathrm{Ar}=298.6\right)$ is indicated with dashed gray lines. In (b), coupled $\delta^{15} \mathrm{~N}-{ }^{40} \mathrm{Ar} /{ }^{36} \mathrm{Ar}$ systematics are investigated in more detail by adjusting the scale. Two samples (NAL-281 and BHE-43) overlap with air, whereas seven sample display ${ }^{40} \mathrm{Ar} /{ }^{36} \mathrm{Ar}$ ratios $\leq$ air. These samples are omitted from further consideration in the discussion. 
892 Figure 6. (a) $\mathrm{N}_{2} /{ }^{3} \mathrm{He}$ and (b) $\mathrm{N}_{2} /{ }^{40} \mathrm{Ar} *$ versus ${ }^{4} \mathrm{He} /{ }^{40} \mathrm{Ar} *$ ratios. Estimates for the ${ }^{4} \mathrm{He} /{ }^{40} \mathrm{Ar} *$, $893 \mathrm{~N}_{2} /{ }^{3} \mathrm{He}$ and $\mathrm{N}_{2} /{ }^{40} \mathrm{Ar} *$ ratios of the upper-mantle (DMM: 1.4 to $4.8 ; 3.76 \pm 1.17\left(\times 10^{6}\right) ; 138 \pm$

894

895

896

897

898

899

900

901

902

903

904

905

906

907

908

909

910

911

912

913

914

915

65, respectively: Marty and Humbert, 1997; Marty and Zimmermann, 1999) are indicated with the dark-yellow box. In (a), we superimpose degassing trajectories for FED and BED assumed starting values of 1.4 and 4.8 (dashed and solid dark-yellow lines) and of 0.1 (dashed and solid blue lines) for ${ }^{4} \mathrm{He} /{ }^{40} \mathrm{Ar} *$ and of $3.76 \pm 1.17\left(\times 10^{6}\right)$ for $\mathrm{N}_{2} /{ }^{3} \mathrm{He}$ and using solubility coefficient described in the text. In (b), we show calculated FED and BED trajectories assuming starting values of 1.4 and 4.8 (dashed and solid dark-yellow lines) for ${ }^{4} \mathrm{He} /{ }^{40} \mathrm{Ar} *$ and $138 \pm 65$ for $\mathrm{N}_{2} /{ }^{40} \mathrm{Ar}^{*}$. Solid blue lines indicate the direction towards a low ${ }^{4} \mathrm{He} /{ }^{40} \mathrm{Ar}^{*}$ melt. The FED trajectory is nearly horizontal irrespective of the ${ }^{4} \mathrm{He} /{ }^{40} \mathrm{Ar} *$ due to the fact that $\mathrm{Ar}$ and $\mathrm{N}$ have similar solubilities in basaltic magmas. The red arrow indicates a possible binary mixing trajectory between (i) a mantle component with low $\mathrm{N}_{2} /{ }^{40} \mathrm{Ar}^{*}$ and ${ }^{4} \mathrm{He}^{40} \mathrm{Ar}^{*}$ ratios, and (ii) a component with high $\mathrm{N}_{2} /{ }^{40} \mathrm{Ar} *$ and ${ }^{4} \mathrm{He} /{ }^{40} \mathrm{Ar} *$ ratios. Since a log-scale is adopted, any uncertainty - derived from combining He with $\mathrm{N}_{2}$ obtained on different crushes - falls within the size of the symbols. See text for details.

Figure 7. (a) ${ }^{4} \mathrm{He}^{40} \mathrm{Ar}^{*}$ and (b) $\mathrm{N}_{2} /{ }^{40} \mathrm{Ar} *$ ratios versus $\delta^{15} \mathrm{~N}$. Estimates for the DMM $(-5 \pm$ 2\%: 1.4 to $4.8: 138 \pm 65$ ) are indicated with the gray box. In (a), we superimpose FED trajectories (see text for details) assuming starting values of 1.4 to 4.8 (dashed gray lines) and of 0.1 for ${ }^{4} \mathrm{He} /{ }^{40} \mathrm{Ar}^{*}$ (dashed blue lines) and $-5 \pm 2 \%$ for $\delta^{15} \mathrm{~N}$ to test the possible effects of magmatic degassing on $\delta^{15} \mathrm{~N}$ values. We also indicated an FED trajectory (dashed black line) starting from the $\delta^{15} \mathrm{~N}$ Iceland mean value of $+1.35 \%$. In (b), $\mathrm{N}_{2} /{ }^{40} \mathrm{Ar} *$ values are plotted versus $\delta^{15} \mathrm{~N}$ to test the possible effects of crustal contamination on modifying $\delta^{15} \mathrm{~N}$ values. With the exception of two samples, all samples have $\mathrm{N}_{2} /{ }^{40} \mathrm{Ar}^{*}>1000$ (horizontal dashed line) 
and there is no clear correlation between $\mathrm{N}_{2} /{ }^{40} \mathrm{Ar} *$ and $\delta^{15} \mathrm{~N}$ arguing against modifications due to the addition of extraneous nitrogen derived from the crust. See text for details.

Figure 8. Plot of (a) $\mathrm{N}_{2} /{ }^{3} \mathrm{He}$ and (b) $\mathrm{N}_{2} /{ }^{40} \mathrm{Ar} *$ ratios versus $\delta^{15} \mathrm{~N}$ values. Only samples with ${ }^{4} \mathrm{He} /{ }^{40} \mathrm{Ar} *<10$ are shown. In (a), two key end-member compositions are indicated: DMM $\left(3.76 \pm 1.17 \times 10^{6} ;-5 \pm 2 \%\right.$ ) and a hybrid Iceland mantle plume source that has incorporated a heterogeneous section of recycled crustal material $\left(1 \pm 6 \times 10^{10} ;+3 \pm 3 \%\right.$ o. Binary mixing trajectories between these end-member compositions are shown with the two dashed gray lines, taking the uncertainties of end-member compositions into account. A binary mixing trajectory from a lower $\mathrm{N}_{2} /{ }^{3} \mathrm{He}$ end-member $\left(\sim 1 \times 10^{6}\right.$ : depleted-DMM $)$ is shown with a solid black line whereas a binary mixing curve involving an even lower $\mathrm{N}_{2} /{ }^{3} \mathrm{He}$ end-member $(\sim 1$ $\times 10^{5}$ : ultradepleted-DMM) is shown with the cyan colored solid line. In (b), the DMM endmember $(138 \pm 65 ;-5 \pm 2 \%)$ and a hybrid Iceland mantle plume source $\left(5 \pm 4 \times 10^{6} ;+3 \pm\right.$ $3 \%$ ) are indicated with gray boxes. Taking the uncertainty of end-member compositions into account, binary mixing trajectories between these end-member compositions are shown with the two dashed gray lines. Significantly, data are consistent with binary mixing involving a heterogeneous recycled nitrogen component. Since a log-scale is adopted, any uncertainty derived from combining $\mathrm{He}$ with $\mathrm{N}_{2}$ obtained on different crushes - falls within the size of the symbols.

Figure 9. Helium isotopes ratios $\left({ }^{3} \mathrm{He} /{ }^{4} \mathrm{He}\right)$ versus $\delta^{15} \mathrm{~N}$ values for the same samples plotted in Figure 8. Also plotted are data from the Reykjanes Ridge reported by Barry et al. (2012). Possible end-member components of DMM $\left(8 \pm 1 \mathrm{R}_{\mathrm{A}} ;-5 \pm 2 \%\right.$ ) and a hybrid Iceland plume with a ${ }^{3} \mathrm{He} /{ }^{4} \mathrm{He}$ ratio of $37 \pm 2 \mathrm{R}_{\mathrm{A}}$ and $\delta^{15} \mathrm{~N}$ values of $+3 \pm 3 \%$ are shown. The relative $\mathrm{N} / \mathrm{He}$ ratios between plume and DMM components is expressed as $r$-values (where $r=$ 
$\left.941(\mathrm{~N} / \mathrm{He})_{\mathrm{PLUME}} /(\mathrm{N} / \mathrm{He})_{\mathrm{DMM}}\right)$. Binary mixing trajectories between DMM and a recycled/plume

942 hybrid component are shown with gray mixing lines for $r=1$, but the cyan mixing line 943 indicates $r=20$. See text for details.

944

\section{Reference}

Barker, A.J. and Gayer, R.A. (1984) Caledonide-Appalachian tectonic analysis and evolution of related oceans. In: Geyer, R.A. (Ed.), The Tectonic Evolution of the CaledonideAppalachian Orogen. International Monograph Series on Interdisciplinary Earth Science Research and Applications. Friedrich Vieweg 7 Sohn, Braunschweig V, 126-165.

Barry, P.H., Hilton, D.R., Halldórsson, S.A., Hahm D. and Marti K. (2012) High precision nitrogen isotope measurements in oceanic basalts using a static triple collection noble gas mass spectrometer. Geochem. Geophys. Geosyst. 13, Q01019.

Barry, P.H., Hilton, D.R., Füri, E., Halldórsson, S.A. and Grönvold, K. (2014) Carbon isotope and abundance systematics of Icelandic geothermal gases, fluids and subglacial basalts with implications for mantle plume-related $\mathrm{CO}_{2}$ fluxes. Geochemica Cosmochimica Acta 134, 7499.

Bebout, G. E., Fogel, M. L. and Cartigny, P. (2013) Nitrogen: Highly volatile yet surprisingly compatible. Elements, 9, 333-338.

963 regions. J. Geophys. Res. 90, 9953-9960. 
967 Bjarnason, I. T. and Schmeling, H. (2009) The lithosphere and asthenosphere of the Iceland 968 hotspot from surface waves. Geophysical Journal International, 178 (1), 394-418.

969

Boyd S. R., Wright I. P. and Pillinger C. T. (1993) Accurate determination of nitrogen

971

972

973

974

975

976

977

978

979

980

981

982

983

984

985

986

987

988

989

concentrations by static vacuum mass spectrometry. Meas. Sci. Technol., 4, 1000-1005.

Brandes, J.A., Boctor, N.Z., Cody, G.D., Cooper, B.A., Hazen, R.M. and Yoder H.S.

(1998) Abiotic nitrogen reduction on the early Earth. Nature 395, 365-367.

Brandon A. D., Graham D. W., Waight T. and Gautason B. (2007) ${ }^{186}$ Os and ${ }^{187}$ Os

enrichments and high- ${ }^{3} \mathrm{He} /{ }^{4} \mathrm{He}$ sources in the Earth's mantle: evidence from Icelandic picrites. Geochim. Cosmochim. Acta 71(18), 4570-4591.

Breddam K., Kurz M. D. and Storey M. (2000) Mapping out the conduit of the Iceland mantle plume with helium isotopes. Earth Planet. Sci. Lett. 176(1), 45-55.

Breddam, K. (2002) Kistufell: primitive melt from the Iceland plume. Journal of Petrology 43, 345-373.

Burnard P. G., Stuart F. M., Turner G. and Oskarsson N. (1994) Air contamination of basaltic magmas: implications for high ${ }^{3} \mathrm{He} /{ }^{4} \mathrm{He}$ mantle Ar isotopic composition. J. Geophys. Res. Sol. Earth 99(B9), 17709-17715. 
990

991

992

993

994

995

996

997

998

999

1000

1001

1002

1003

1004

1005

1006

1007

1008

1009

1010

1011

1012

1013

1014

Burnard, P.G. and Harrison, D. (2005) Argon isotope constraints on modification of oxygen isotopes in Iceland basalts by surficial processes. Chemical Geology 216 (1-2), 143-156.

Busigny V., Laverne C. and Bonifacie M. (2005) Nitrogen content and isotopic composition of oceanic crust at a superfast spreading ridge: a profile in altered basalts from ODP Site 1256, Leg 206. Geochem. Geophys. Geosyst. 6, Q12O01.

Busigny, V., Cartigny, P. and Philippot P. (2011) Nitrogen isotopes in ophiolitic metagabbros: A re-evaluation of modern nitrogen fluxes in subduction zones and implication for the early Earth atmosphere. Geochim. Cosmochim. Acta 75, 7502-7521.

Busigny, V. and Bebout, G. E. (2013) Nitrogen in the silicate Earth: Speciation and isotopic behavior during fluid-mineral interactions. Elements 9, 353-358.

Cartigny, P., Jendrzejewski, F., Pineau, F., Petit, E. and Javoy, M. (2001) Volatile (C, N, Ar) variability in MORB and the respective roles of mantle source heterogeneity and degassing: the case of the Southwest Indian Ridge. Earth Planet. Sci. Lett. 194, 241-257.

Cartigny P. and Ader M. (2003) A comment to "The nitrogen record of crust-mantle interaction and mantle convection from Archean to Present" by B. Marty and N. Dauphas." Earth Planet. Sci. Lett. 216, 425-432

Cartigny P., and Marty B. (2013) Nitrogen isotopes and mantle geodynamics: the emergence of life and the atmosphere-crust-mantle-connection. Elements 9, 353-366. 
Chauvel C. and Hemond C. (2000) Melting of a complete section of recycled oceanic crust: trace element and $\mathrm{Pb}$ isotopic evidence from Iceland. Geochem. Geophys. Geosyst. 1(2), 1001, doi:10.1029/1999GC000002.

Condomines M., Grönvold K., Hooker P. J., Muehlenbachs K., O’Nions R. K., Oskarsson N. and Oxburgh E. R. (1983) Helium, oxygen and strontium isotopic relationships in Icelandic volcanics. Earth Planet. Sci. Lett. 66, 125-136.

Courtillot, V., Davaille, A., Besse, J. and Stock J. (2003) Three distinct types of hotspots in the Earth's mantle. Earth Planet. Sci. Lett. 205, 295-308.

Craig, H. and Lupton, J.E. (1976) Primordial neon, helium, and hydrogen in oceanic basalts. Earth Planet. Sci. Lett. 31, 369- 385.

Craig, H., Marti, K. and Wiens, R. (1993) A Static Mass Spectrometer With Triple Collection for Nitrogen and Neon Isotopes, SIO Reference Ser., vol. 93-11, pp. 1-20A, Scripps Inst. of Oceanogr., La Jolla, Calif.

Dauphas, N. and Marty, B. (1999) Heavy nitrogen in carbonatites of the Kola Peninsula: a possible signature of the deep mantle. Science 286, 2488-2490.

de Leeuw G. A. M. (2007) The noble gas and carbon systematics of divergent, convergent and strike-slip plate boundaries: examples from the Reykjanes Ridge, Central American Arc and North Anatolian Fault Zone. Ph.D. thesis, University of California, San Diego. 
1040

1041

1042

1043

1044

1045

1046

1047

1048

1049

1050

1051

1052

1053

1054

1055

1056

1057

1058

1059

1060

1061

1062

1063

1064

Debaille V, Trønnes R.G., Brandon A.D., Waight T.E., Graham D.W. and Lee C.A. (2009)

Primitive off-rift basalts from Iceland and Jan Mayen: Os-isotopic evidence for a mantle source containing enriched subcontinental lithosphere. Geochim. Cosmochim. Acta 73(11), $3423-3449$.

Dixon E. T. (2003) Interpretation of helium and neon isotopic heterogeneity in Icelandic basalts. Earth Planet. Sci. Lett. 206(1-2), 83-99.

Dixon E. T., Honda M., McDougall I., Campbell I. H. and Sigurdsson I. (2000) Preservation of near-solar neon isotopic ratios in Icelandic basalts. Earth Planet. Sci. Lett. 180(3-4), 309324.

Ellam R. M. and Stuart F. M. (2004) Coherent He-Nd-Sr isotope trends in high ${ }^{3} \mathrm{He} /{ }^{4} \mathrm{He}$ basalts: implications for a common reservoir, mantle heterogeneity and convection. Earth Planet. Sci. Lett. 228(3-4), 511-523.

Exley, R.A., Boyd, S.R., Mattey, D.P. and Pillinger, C.T. (1986) Nitrogen isotope geochemistry of basaltic glasses: implications for mantle degassing and structure? Earth Planet. Sci. Lett. 81, 163-174.

Fischer, T.P., Takahata, N., Sano, Y., Sumino, H. and Hilton, D.R. (2005) Nitrogen isotopes of the mantle: insights from mineral separates. Geophys. Res. Lett. 32, 2005 GL022792.

Fisk M. R., Storrie-Lombardi M. C., Douglas S., Popa R., McDonald, G. andDi Meo-Savoie C. (2003) Evidence of biological activity in Hawaiian subsurface basalts, Geochem. Geophys. 
Geosyst. 4 2003GC000387.

Fitton J. G., Saunders A. D., Kempton P. D. and Hardarson B. S. (2003) Does depleted mantle form an intrinsic part of the Iceland plume? Geochem. Geophys. Geosyst. 4, 1032.

Furnes H., Muehlebachs K., Torsvik T., Thorseth I. H. and Tumyr O. (2001) Microbial fractionation of carbon isotopes in altered basaltic glass from the Atlantc Ocean, Lau Basin and Costa Rica Rift. Chem. Geol. 173, 313-330.

Füri, E., Hilton, D.R., Halldorsson, S.A., Barry, P.H., Hahm, D., Fischer, T.P. and Gronvold, K. (2010) Apparent decoupling of the He and Ne isotope systematics of the Icelandic mantle: the role of He depletion, melt mixing, degassing fractionation and air interaction. Geochim. Cosmochim. Acta 74, 3307-3332.

Gautason B. and Muehlenbachs K. (1998) Oxygen isotopic fluxes associated with hightemperature processes in the rift zones of Iceland. Chem. Geol. 145(3-4), 275-286.

Goldblatt, C., A. J. Matthews, M. W. Claire, T. M. Lenton, A. J. Watson and Zahnle, K. J. (2009) Nitrogen-enhanced greenhouse warming on early Earth, Nature Geoscience, 2(12), 891-896.

Graham, D.W. (2002) Noble gas isotope geochemistry of mid-ocean ridge and ocean island basalts: characterization of mantle source reservoirs. In: Porcelli, D., Ballentine, C.J., Wieler, R. (Eds.), Noble Gases in Geochemistry and Cosmochemistry. Rev. Mineral. Geochem. Mineral. Soc. Am., vol. 47. Washington, DC, pp. 247-317. 
Hahm D., Hilton D. R., Castillo P. R., Hawkins J. W., Hanan B. B. and Hauri E. H. (2012) An 113.

Halama R., Bebout G.E., John T. and Schenk, V. (2010) Nitrogen recycling in subducted oceanic lithosphere: the record in high- and ultrahigh-pressure metabasaltic rocks. Geochim. Cosmochim. Acta 74, 1636-1652.

Halama R., Bebout, G.E., John, T. and Scambelluri M. (2014) Nitrogen recycling in subducted mantle rocks and implications for the global nitrogen cycle. Int. J. Earth Sci. 103, 7, 2081-2099.

Hanan B. B. and Schilling, J.-G. (1997) The dynamic evolution of the Iceland mantle plume: the $\mathrm{Pb}$ isotope perspective. Earth Planet. Sci. Lett. 151, 43-60.

Hanan B. B., Blichert-Toft J., Kingsley R. and Schilling J. (2000) Depleted Iceland mantle plume geochemical signature: Artifact of multicomponent mixing? Geochem. Geophys. Geosyst. 1, 1003.

Hanyu, T., Tatsumi, Y. and Kimura J-I. (2011) Constraints on the origin of the HIMU reservoir from He-Ne-Ar isotope systematics. Earth Planet. Sci. Lett. 307, 377-386. 
Harrison D., Burnard P. and Turner G. (1999) Noble gas behaviour and composition in the mantle: constraints from the Iceland Plume. Earth Planet. Sci. Lett. 171(2), 199-207.

Hayden, L. A. and Watson, E. B. (2007) A diffusion mechanism for core-mantle interaction. Nature 450, 709-711.

He, Y., Wen, L., Capdeville, Y. and Zhao, L. (2015) Seismic evidence for an Iceland thermochemical plume in the Earth's lowermost mantle. Earth Planet. Sci. Lett. 471(1), 19-27.

Helmberger D., Wen L. and Ding, X. (1998) Seismic evidence that the source of the Iceland hotspot lies at the core-mantle boundary. Nature 396, 251-258.

Hilton, D. R., Grönvold, K., O’Nions, R. K. and Oxburgh E. R. (1990) Regional distribution of ${ }^{3} \mathrm{He}$ anomalies in the Icelandic crust. Chem. Geol. 88, 53-67.

Hilton, D. R. (1996) The helium and carbon isotope systematics of a continental geothermal system: results from monitoring studies at Long Valley caldera (California, U.S.A.). Chem. Geol. 127, 269-295.

Hilton D. R., Grönvold K., Macpherson C. G. and Castillo P. R. (1999) Extreme ${ }^{3} \mathrm{He} /{ }^{4} \mathrm{He}$ ratios in northwest Iceland: constraining the common component in mantle plumes. Earth Planet. Sci. Lett. 173(1), 53-60. 
Hilton, D. R., Thirlwall, M. F., Taylor, R. N., Murton, B. J. and Nichols, A. (2000) Controls on degassing along the Reykjanes Ridge with implications for the helium paradox. Earth Planet. Sci. Lett. 183, 43-50.

\section{Hilton D.R., Halldórsson S.A., Barry P. H., Fischer T. P., de Moor J. M., Ramirez C. J.,} Mangasini F. and Scarsi P. (2011) Helium isotopes at Rungwe Volcanic Province, Tanzania, and the origin of East African Plateaux. Geophysical Research Letters 38, L21304.

Hofmann A.W. and White W.M. (1982) Mantle plumes from ancient oceanic crust. Earth Planet. Sci. Lett. 57, 421-436.

Holland, G., and Ballentine, C.J., (2006) Seawater subduction controls the heavy noble gas composition of the mantle. Nature, 441, 186-191.

\section{Jakobsson S.P. and Gudmundsson M.T. (2008) Subglacial and intraglacial volcanic} formations in Iceland. Jökull 58, 179-197.

Jambon A., Weber H. W. and Braun O. (1986) Solubility of He, Ne, Ar, Kr and Xe in a basalt melt in the range $1250-1600^{\circ} \mathrm{C}$ - Geochemical implications. Geochim. Cosmochim. Acta 50, 401-408.

Javoy, M., Pineau, F. and Delorme, H. (1986) Carbon and nitrogen isotopes in the mantle. Chem. Geol. 57, 41-62. 
Javoy M. and Pineau F. (1991) The volatile record of a popping rock from the Mid-Atlantic Ridge at $14^{\circ} \mathrm{N}$ : Chemical and isotopic composition of gases trapped in the vesicles, Earth Planet. Sci. Lett. 107, 598-611.

Javoy, M. (1995) The integral Enstatite Chondrite model of the Earth. Geophys. Res. Lett. 22, 2219-2222.

Javoy M. (1997) The major volatile elements of the Earth: their origin, behavior, and fate. Geophys. Res. Lett. 24, 177-180.

Javoy M. (1998) The birth of the Earth's atmosphere: the behaviour and fate of its major elements. Chem. Geol. 147, 11-25.

Jóhannesson H., and Sæmundsson, K. (1998) Geological map of Iceland. Bedrock geology, scale 1:500.000. Náttúrufraðistofnun Islands, Reykjavík (2nd edition).

Johnson, B. and Goldblatt, C. (2015) The Nitrogen Budget of Earth. Earth Science Reviews, in press.

Kempton P. D., Fitton J. G., Saunders A. D., Nowell G. M., Taylor R. N., Hardarson B. S. and Pearson G. (2000) The Iceland plume in space and time: a Sr-Nd-Pb-Hf study of the North Atlantic rifted margin. Earth Planet. Sci. Lett. 177(3-4), 255-271.

Kienast M. (2000) Unchanged nitrogen isotopic composition of organic matter in the South China Sea during the last climatic cycle: global implications, Paleoceanography 15, 244-253. 
1187 Kokfelt T.F., Hoernle K., Hauff F., Fiebig J., Werner R. and Garbe-Schönberg D. (2006)

1188 Combined trace element and $\mathrm{Pb}-\mathrm{Nd}-\mathrm{Sr}-\mathrm{O}$ isotope evidence for recycled oceanic crust (upper 1189 and lower) in the Iceland mantle plume. J. Petrol. 47(9),1705-1749.

Kurz, M.D., Jenkins W.J. and Hart, S.R. (1982) Helium isotopic systematics of ocean islands and mantle heterogeneity. Nature 297, 43-47.

1193

Kurz, M.D., Meyer P.S. and Sigurdsson H. (1985) Helium isotopic systematics within the neovolcanic zones of Iceland. Earth Planet. Sci. Lett. 74(4), 291-305.

Lang, S. Q., Butterfield D. A., Lilley M. D., Johnson H. P. and Hedges J. I. (2006) Dissolved organic carbon in ridge-axis and ridge-flank hydrothermal systems. Geochim. Cosmochim. Acta 70, 3830-3842.

Lee, J. Y., Marti K., Severinghaus J. P., Kawamura K., Yoo H. S., Lee J. B. and Kim J. S. (2006) A redetermination of the isotopic abundances of atmospheric Ar. Geochim. Cosmochim. Acta 70, 4507-4512.

1204

Li, L., Bebout, G.E. and Idleman, B.D. (2007) Nitrogen concentration and $\delta^{15} \mathrm{~N}$ of altered oceanic crust obtained on ODP Legs 129 and 185: insights into alteration-related nitrogen enrichment and the nitrogen subduction budget. Geochim. Cosmochim. Acta 71, 2344-2360. 
minerals. Earth Planet. Sci. Lett. 377-378, 311-323.

1211

1212 Li Y. and Keppler H. (2014) Nitrogen speciation in mantle and crustal fluids. Geochim.

1213 Cosmochim. Acta 129, 13-32.

1214

1215

Libourel G., Marty B. and Humbert F. (2003) Nitrogen solubility in basaltic melt. Part I.

Effect of oxygen fugacity. Geochim. Cosmochim. Acta 67, 4123-4135.

1217

1218

Licciardi J. M., Kurz M. D. and Curtice J. M. (2007) Glacial and volcanic history of Icelandic

1219

1220

table mountains from cosmogenic ${ }^{3} \mathrm{He}$ exposure ages. Quaternary Science Reviews, 26(11), 1529-1546.

1221

1222

Licciardi J.M., Kurz M.D. and Curtice J.M. (2006) Cosmogenic 3He production rates from

1223

Holocene lava flows in Iceland. Earth Planet. Sci. Lett. 246, 251-264.

1224

1225

1226

1227

Iceland lavas, Earth Planet Sci. Lett. 233, 411-427.

1228

1229

Magna T., Wiechert U., Stuart F.M., Halliday A.N. and Harrison D. (2011) Combined Li-He

isotopes in Iceland and Jan Mayen basalts and constraints on the nature of the North Atlantic

mantle. Geochimica et Cosmochimica Acta 75 (3), 922-936.

1232

1233

Marty B., Zashu S. and Ozima M. (1983) Two noble gas components in a Mid-Atlantic Ridge basalt. Nature 302, 238-240. 
1236 Marty B., Gunnlaugsson E., Jambon A., Oskarsson N., Ozima M., Pineau F. and Torssander

1237

1238

1239

1240

1241

1242

1243

1244

1245

1246

1247

1248

1249

1250

1251

1252

1253

1254

1255

1256

1257

1258

1259

P. (1991) Gas geochemistry of geothermal fluids, the Hengill Area, southwest rift zone of Iceland. Chem. Geol. 91(3), 207-225.

Marty, B. (1995) Nitrogen content of the mantle inferred from N2-Ar correlation in oceanic basalts. Nature 377, 326-329.

Marty, B. and Humbert, F. (1997) Nitrogen and argon isotopes in oceanic basalts, Earth Planet. Sci. Lett. 152, 101-112.

Marty, B. and Zimmermann L. (1999) Volatiles (He, C, N, Ar) in mid-ocean ridge basalts: assessment of shallow-level fractionation and characterization of source composition.

Geochim. Cosmochim. Acta 63, 3619-3633.

Marty B. (2012) The origins and concentrations of water, carbon, nitrogen and noble gases on Earth. Earth Planet. Sci. Lett. 313-314, 56-66.

Marty, B. and Dauphas N. (2003a) The nitrogen record of crust-mantle interaction and mantle convection from Archean to Present. Earth Planet. Sci. Let. 206, 397-410.

Marty, B. and Dauphas, N. (2003b) "Nitrogen isotopic compositions of the present mantle and the Archean biosphere": Reply to comment by Pierre Cartigny and Magali Ader. Earth Planet. Sci. Let. 216, 433-439. 
1260

1261

1262

1263

1264

1265

1266

1267

1268

1269

1270

1271

1272

1273

1274

1275

1276

1277

1278

1279

1280

1281

1282

1283

1284

Matsuda J. I. and Marty B. (1995) The ${ }^{40} \mathrm{Ar} /{ }^{36} \mathrm{Ar}$ ratio of the undepleted mantle; A

reevaluation. Geophys. Res. Lett. 22, 1937-1940.

Matsuo S., M. Susuki and Mizutani, Y. (1978) Nitrogen to argon ratio in volcanic gases. in

Terrestrial Rare Gases (eds. E.C. Alexander \& M. Ozima). Center for Academic Publishing Japan, Tokyo, 17- 25.

McKenzie D., Stracke A., Blichert T.J., Albarede F., Grönvold K. and O‘Nions. R.K. (2004)

Source enrichment processes responsible for isotopic anomalies in oceanic island basalts.

Geochim. Cosmochim. Acta 68 (12), 2699-2724.

Mehegan J., Robinson J. and Delaney J. (1982) Secondary mineralization and hydrothermal alteration in the Reydarfjordur Drill Core, East Iceland, J. Geophys. Res. 87, 6511 - 6524.

Moreira M. and Sarda P. (2000) Noble gas constraints on degassing processes. Earth Planet. Sci. Lett. 176(3-4), 375-386.

Mukhopadhyay S. (2012) Early differentiation and volatile accretion recorded in deep-mantle neon and xenon. Nature 486, 101-104.

Miyazaki A., Hiyagon H., Sugiura N., Hirose K. and Takahashi E. (2004) Solubilities of nitrogen and noble gases in silicate melts under various oxygen fugacities: implications for the origin and degassing history of nitrogen and noble gases in the Earth. Geochim.

Cosmochim. Acta 68, 387-401. 
Mysen, B. O. Shigeru Yamashita, S. and Chertkova, N. (2008) Solubility and Solution Mechanisms of NOH Volatiles in Silicate Melts at high Pressure and Temperature - Amine Groups and Hydrogen Fugacity. Amer. Mineral. 93, 1760-1770.

Mysen, B. O. and Fogel, M. L. (2010) Nitrogen and Hydrogen Isotope Compositions and Solubility in Silicate Melts in Equilibrium with Reduced $(\mathrm{N}+\mathrm{H})$-bearing Fluids at High Pressure and Temperature: Effects of Melt Structure. Amer. Mineral. 95, 987-999.

Mohapatra, R. K., Harrison, D. Ott, U. Gilmour, J. D. and Trieloff M. (2009) Noble gas and nitrogen isotope components in Ocean Island Basalts. Chem. Geol. 266, 29-37.

Neuhoff, P.S., Fridriksson, T., Arnórsson, S. and Bird, D.K. (1999) Porosity changes and mineral paragenesis during low-grade metamorphism at Teigarhorn, eastern Iceland. American Journal of Science 299, 467-501.

Neuhoff, P.S., Fridriksson, T. and Bird, D.K. (2000) Zeolite Parageneses in the North Atlantic Igneous Province: Implications for Geotectonics and Groundwater Quality of Basaltic Crust. International Geology Review 42, 15-44.

Nishio, Y., Ishii, T. Gamo, T. and Sano, Y. (1999) Volatile element isotopic systematics of the Rodriguez Triple Junction Indian Ocean MORB: implications for mantle heterogeneity. Earth Planet. Sci. Lett. 170, 241-253. 
Palot, M., Cartigny, P. Harris, J.W. Kaminsky, F.V. and Stachel, T. (2012) Evidence for deep mantle convection and primordial heterogeneity from nitrogen and carbon stable isotopes in diamond. Earth Planet. Sci. Lett. 357-358, 179-193.

Peate D.W., Breddam K., Baker J.A., Kurz M.D., Barker A.K. and Prestvik T., Grassineau N., Skovgaard A.C. (2010) Compositional characteristics and spatial distribution of enriched Icelandic mantle components. J. Petrol. 51(7), 1447-1475.

Peters K. E., Sweeny R. E. and Kaplan I. R. (1978) Correlation of carbon and nitrogen stable isotope ratios in sedimentary organic matter. Limnol. Ocean. 23, 598-604.

Pinti D. L., Hashizume K. and Matsuda J. I. (2001) Nitrogen and argon signatures in 3.8 to 2.8 Ga metasediments: Clues on the chemical state of the Archean ocean and the deep biosphere. Geochim. Cosmochim. Acta 65, 2301-2316.

Pinti D. L., Hashizume K., Orberger B., Gallien J.-P., Cloquet C. and Massault M. (2007) Biogenic nitrogen and carbon in $\mathrm{Fe}-\mathrm{Mn}$-oxyhydroxides from an Archan chert, Marble Bar, Western Australia. Geochem. Geophys. Geosyst. 8, Q02007.

Pinti, D.L. and Hashizume, K. (2010) Early life recorded by nitrogen isotopes. In: Golding, S., Glikson, M. (Eds.), Earliest Life on Earth: Habitats, Environments and Methods of Detection. Springer-Verlag, The Netherlands, pp. 183-205. 
Polak, G., Kononov, I., Tolstikhin, I.N., Mamyrin, B.A. and Khabarin, L.V. (1976). The helium isotopes in thermal fluids. Thermal and Chemical Problems of Thermal Waters. Int. Assoc. Hydrogeol. Sci., pp. 17- 33.

Poreda R., Shilling J. G. and Craig H. (1986) Helium and hydrogen isotopes in ocean-ridge basalts north and south of Iceland, Earth Planet. Sci. Lett. 78, 1-17.

Richet, P., Bottinga, Y. and Javoy, M. (1977) A review of hydrogen, carbon, nitrogen, oxygen, sulphur and chlorine stable isotope fractionation among gaseous molecules. Annu. Rev. Earth Planet. Sci. 82, 269-279.

Roskosz, M., Mysen, B. O. and Cody, G. D. (2006) Dual speciation of nitrogen in silicate melts at high pressure and temperature: An experimental study. Geochim. Cosmochim. Acta. 70, 2902-2918.

Roskosz, M., Bouhifd, M. A., Jephcoat, A. P., Marty, B. and Mysen, B. O. (2013) Nitrogen solubility in molten metal and silicate at high pressure and temperature. Geochim. Cosmochim. Acta. 121, 15-28.

Roulleau, E., Pinti, D.L. Stevenson, R.K., Takahata, N., Sano, Y. and Pitre, F. (2012) N, Ar and $\mathrm{Pb}$ isotopic co-variations in magmatic minerals: Discriminating fractionation processes from magmatic sources in Monteregian Hills, Québec, Canada. Chem. Geol. 326-327, 123131. 
Sakai, H., Des Marais, D.J., Ueda, A. and Moore, J.G. (1984) Concentrations and isotope ratios of carbon, nitrogen and sulfur in ocean-floor basalts. Geochim. Cosmochim. Acta. 48, $2433-2441$.

Sano Y., Takahata N., Nishio Y. and Marty B. (1998) Nitrogen recycling in subduction zones, Geophys. Res. Lett. 25, 2289-2292.

Sarda, P., Moreira, M. and Staudacher, T. (1999). Argon-lead isotopic correlation in MidAtlantic Ridge basalts. Science 283, 666-668.

Sarda, P. and Moreira, M. (2002) Vesiculation and vesicle loss in mid-ocean ridge basalt glasses: $\mathrm{He}, \mathrm{Ne}$, Ar elemental fractionation and pressure influence. Geochimica et Cosmochimica Acta 66, 1449-1458.

Shaw, A.M., Hilton, D.R., Fischer, T.P., Walker, J.A. and De Leeuw, G.A. (2006) Helium isotope variations in mineral separates from Costa Rica and Nicaragua: Assessing crustal contributions, time scale variations and diffusion-related mechanisms. Chem. Geol. 230, 124139.

Skovgaard, A. C., Storey, M., Baker, J. A., Blusztajn, J. and Hart, S. R. (2001) Osmiumoxygen isotopic evidence for a recycled and strongly depleted component in the Iceland mantle plume. Earth Planet. Sci. Lett. 194, 259-275.

Soper, N.J., Strachan, R.A., Holdsworth, R.E., Gayer, R.A. and Greiling, R.O. (1992) Sinistral transpression and the Silurian closure of Iapetus. J. Geol. Soc. (Lond.) 149, 871-880. 
1381 Sobolev, A.V., Hofmann, A.W., Brügmann, G., Batanova, V. G. and Kuzmin D. V. (2008) A quantitative link between recycling and osmium isotopes. Science 321, 536.

1383

Sobolev, A.V., Hofmann, A.W., Jochum, K.P., Kuzmin, D.V. and Stoll B. (2011) A young source for the Hawaiian plume. Nature 476, 434-437.

1386

1387

Sun, W.D., Bennett, V.C. and Kamenetsky, V.S. (2004) The mechanism of Re enrichment in arc magmas: evidence from Lau Basin basaltic glasses and primitive melt inclusions. Earth Planet. Sci. Lett. 222, 101-114.

Stracke, A., Zindler, A., Salters, V. J. M., McKenzie, D., Blichert-Toft, J., Albarede, F. and

Grönvold, K. (2003) Theistareykir revisited. Geochemistry, Geophysics, Geosystems 4(2), 8507, doi:10.1029/2001GC000201.

1394 resolving mantle and crustal contributions to hydrothermal fluids. In Noble Gas Geochemistry and Cosmochemistry (ed. J. Matsuda). Terra Scientific Publishing Company, Tokyo, pp. 261277.

Thirlwall M. F. (1995) Generation of the Pb isotopic characteristics of the Iceland plume. $J$. Geol. Soc. 152, 991-996. HIMU mantle. Chem. Geol. 139, 51-74. 
1406 Thirlwall M. F., Gee M. A. M., Taylor R. N. and Murton B. J. (2004) Mantle components in 1407 Iceland and adjacent ridges investigated using double-spike $\mathrm{Pb}$ isotope ratios. Geochim. 1408 Cosmochim. Acta 68(2), 361-386.

1409

1410 Thirlwall M. F., Gee M. A. M., Lowry D., Mattey D. P., Murton B. J. and Taylor R. N. (2006)

1411 Low $\delta^{18} \mathrm{O}$ in the Icelandic mantle and its origins: evidence from Reykjanes Ridge and 1412 Icelandic lavas. Geochim. Cosmochim. Acta 70, 993-1019.

1413

1414 Thorseth, I. H., Furnes H. and Heldal M. (1992) The importance of microbiological activity in 1415 the alteration of natural basaltic glass, Geochim. Cosmochim. Acta, 56, 845-850.

1416

1417 Thomazo, C. and Paineau, D. (2013) Biogeochemical cycling of nitrogen on the Early Earth. 1418 Elements, 9(5), 345-351.

1419

1420 Tolstikhin, I.N. and Marty, B. (1998) The evolution of terrestrial volatiles: a view from 1421 helium, neon, argon and nitrogen isotope modelling. Chem. Geol. 147, 27-52.

1422

1423 Trieloff M., Kunz J., Clague D. A., Harrison D. and Allégre C. J. (2000) The nature of 1424 pristine noble gases in mantle plumes. Science 288, 1036-1038.

1426 Trosvik, T.H. et al. (2015) Continental crust beneath southeast Iceland. PNAS 112, 15 1427 E1818-E1827. 
1429 Tuffen H., Owen J. and Denton J. (2010) Magma degassing during subglacial eruptions and 1430 its use to reconstruct palaeo-ice thicknesses. Earth-Sci Rev. 99(1-2), 1-18.

1431

1432 White, W.M. (2010) Oceanic Island Basalts and Mantle Plumes: The Geochemical

1433 Perspective. Annu. Rev. Earth Planet. Sci. 38, 133-160.

1434

1435 Yamamoto, J. and Burnard, P. (2005) Solubility controlled noble gas fractionation during

1436 magmatic degassing: implications for noble gas compositions of primary melts of OIB and

1437 MORB. Geochimica et Cosmochimica Acta 69(3), 727-734.

1438

1439 Yokochi, R. and Marty B. (2006) Fast chemical and isotopic exchange of nitrogen during

1440 reaction with hot molybdenum. Geochem. Geophys. Geosyst. 7, Q07004, doi:10.1029/

$14412006 \mathrm{GC} 001253$.

1442

1443 Yokochi, R., Marty, B., Chazot, G., and Burnard P. (2009) Nitrogen in peridotite xenoliths:

1444 Lithophile behavior and magmatic isotope fractionation. Geochim. Cosmochim. Acta 73,

$1445 \quad 4843-4861$.

1446

1447

1448

1449

1450

1451 


\section{TABLES}

Table 1: Nitrogen, argon and helium abundance and isotope systematics of subglacial basaltic glasses from the neo-volcanic zones of Iceland

\begin{tabular}{|c|c|c|c|c|c|c|c|c|c|c|c|c|c|}
\hline Sample Id $^{\mathrm{a}}$ & Locality & $\begin{array}{c}\text { Sample wt. } \\
\text { [g] for } N_{2}\end{array}$ & $\begin{array}{c}{\left[\mathrm{N}_{2}\right] 10^{-6} \mathrm{~cm}^{3}} \\
\operatorname{STP} / \mathrm{g}( \pm 2.5 \%)^{\mathrm{b}}\end{array}$ & $\begin{array}{l}\delta^{15} \mathrm{~N} \\
(\%)\end{array}$ & $\begin{array}{l} \pm \\
10\end{array}$ & $\begin{array}{l}\mathrm{N}_{2} / \mathrm{Ar} \\
\mathrm{QMS}^{\mathrm{c}}\end{array}$ & $\begin{array}{l}{\left[^{40} \mathrm{Ar}\right] 10^{-9} \mathrm{~cm}^{3}} \\
\mathrm{STP} / \mathrm{g}( \pm 2.5 \%)\end{array}$ & $\begin{array}{l}{ }^{{ }^{40} \mathrm{Ar} /{ }^{36} \mathrm{Ar}} \\
( \pm 2.5 \%)\end{array}$ & $\begin{array}{l}{[\mathrm{He}] 10^{-9} \mathrm{~cm}^{3}} \\
\mathrm{STP} / \mathrm{g}( \pm 5 \%)\end{array}$ & $\begin{array}{c}{ }^{3} \mathrm{He} /{ }^{4} \mathrm{He} \text { (R/RA) } \\
( \pm 2.5 \%)\end{array}$ & $\begin{array}{c}\mathrm{N}_{2} /{ }^{3} \mathrm{He} 10^{7} \\
( \pm 5 \%)^{\mathrm{d}}\end{array}$ & $\begin{array}{l}\mathrm{N}_{2}{ }^{40} \mathrm{Ar}^{*} \\
( \pm 5 \%)^{\mathrm{e}}\end{array}$ & $\begin{array}{r}{ }^{4} \mathrm{He}{ }^{40} \mathrm{Ar}^{*} \\
( \pm 5 \%)^{\mathrm{d}}\end{array}$ \\
\hline \multicolumn{14}{|l|}{ WRZ } \\
\hline VIF-1* & Vífilsfell & 2.6324 & $73.8(2 \%)$ & 2.43 & 0.14 & 126 & 85.4 & 346.2 & 45.18 & 12.97 & 9.0 & 316 & 1.2 \\
\hline MID-1* & Miơfell & 1.2786 & $21.1(4 \%)$ & 0.65 & 0.19 & 152 & 2234.0 & 1334.5 & 3447 & 17.2 & 0.025 & 3755 & 3.2 \\
\hline dup & & 0.6385 & $31.6(22 \%)$ & 2.12 & 0.36 & 153 & & & & & & & \\
\hline dup & & 1.0219 & $22.0(11 \%)$ & 3.72 & 0.72 & & & & & & & & \\
\hline dup & & 1.4225 & $31.7(7 \%)$ & 0.81 & 0.49 & 145 & & & & & & & \\
\hline dup & & 1.899 & $25.1(5 \%)$ & 1.14 & 0.38 & 115 & & & & & & & \\
\hline dup & & 1.5448 & $24.0(6 \%)$ & 1.64 & 0.48 & 161 & & & & & & & \\
\hline MID-3* & Kálfstindar & 1.4034 & $33.7(7 \%)$ & -0.03 & 0.65 & 104 & 2290.9 & 309.0 & 868.19 & 14.1 & 0.2 & 323978 & 2.1 \\
\hline NES-1 & Nesjavellir & 2.5083 & $30.2(3 \%)$ & 0.64 & 0.47 & 85 & 671.0 & 297.1 & 139.64 & 15.8 & 0.98 & & \\
\hline OLF-1 & Ölfusvatnsfjöll & 1.7566 & $2.11(41 \%)$ & 4.31 & 0.74 & & 27.2 & 1076.4 & 258.17 & 14.5 & 0.04 & & 5.1 \\
\hline REY-1 & Reykjanesviti & 2.3622 & $66.1(3 \%)$ & 4.13 & 0.39 & 133 & 3303.4 & 296.6 & 623.43 & 14.2 & 0.53 & & \\
\hline MAE-1 & Mælifell & 2.5047 & $2.50(30 \%)$ & 2.08 & 0.36 & 172 & 14.8 & 433.0 & 400.04 & 12.5 & 0.036 & 117 & 3.4 \\
\hline A1 & Ármannsfell & 2.5333 & $17.0(8 \%)$ & 1.67 & 0.44 & 239 & 329.3 & 303.6 & 168.51 & 15.3 & 0.47 & 72915 & 31.6 \\
\hline$A 2^{*}$ & Pórólfsfell & 2.857 & $29.7(4 \%)$ & -2.29 & 0.47 & 407 & 208.6 & 750.8 & 154.03 & 14.0 & 0.98 & 3588 & 4.3 \\
\hline dup & & 2.9575 & $5.09(17 \%)$ & 1.63 & 0.56 & & & & & & & & \\
\hline$A 6^{*}$ & Bláfell & 3.0734 & $5.78(17 \%)$ & 0.97 & 1.41 & 122 & 526.0 & 303.3 & 50.36 & 15.4 & 0.53 & 17486 & 2.7 \\
\hline$A 9^{*}$ & Arnarbæli & 2.5162 & $28.1(4 \%)$ & 5.71 & 0.48 & 278 & 247.3 & 419.3 & 831.47 & 21.1 & 0.11 & 9869 & 4.8 \\
\hline dup & & 2.5809 & $10.1(15 \%)$ & 6.16 & 0.15 & 118 & & & & & & & \\
\hline \multicolumn{14}{|l|}{ NRZ } \\
\hline NAL-216 & Hvammsfjöll & 2.5020 & $17.5(7 \%)$ & 1.80 & 0.42 & 138 & 258.2 & 330.7 & 578.61 & 12.8 & 0.17 & 22635 & 24.7 \\
\hline NAL-263* & V-Skógamannafjöll & 2.1051 & $83.8(2 \%)^{\prime}$ & 3.70 & 0.64 & 99 & 9578.7 & 316.3 & 2826.9 & 9.2 & 0.23 & 1265336 & 4.9 \\
\hline dup & & 2.5374 & $45.5(4 \%)$ & 4.71 & 0.37 & 87 & & & & & & & \\
\hline NAL-281 & Herðubreiðarfjöll & 1.6527 & $77.5(2 \%)$ & -0.01 & 0.45 & 104 & 7349.3 & 298.0 & 1255 & 10.4 & 0.42 & & \\
\hline NAL-356 & Upptyppingar & 2.5776 & $7.43(13 \%)$ & -1.78 & 0.52 & 233 & 655.3 & 292.7 & 58.2 & 8.5 & 1.1 & & \\
\hline dup & & 2.7766 & $6.24(15 \%)$ & -2.72 & 0.57 & & & & & & & & \\
\hline NAL-500 & Gæsahnjúkar & 2.3804 & $18.7(7 \%)$ & 1.58 & 0.64 & 95 & 1927.1 & 295.9 & 205.34 & 17.6 & 0.37 & & \\
\hline NAL584 & Dyngjufjöll Ytri & 3.1641 & $7.74(10 \%)$ & 3.35 & 1.00 & 177 & 101.5 & 340.4 & 53.1 & 19.7 & 0.53 & 2755 & 12.0 \\
\hline NAL585* & Upptyppingar & 2.9882 & $10.1(8 \%)$ & -1.20 & 0.53 & 152 & 138.2 & 311.8 & 58.58 & 8.7 & 1.4 & 15805 & 5.1 \\
\hline NAL-595* & Kistufell & 1.4448 & $41.6(5 \%)$ & -1.49 & 0.47 & & 5595.6 & 306.3 & 916.96 & 15.7 & 0.21 & & 9.8 \\
\hline NAL600* & Urðarháls & 2.2882 & $45.4(4 \%)$ & 0.97 & 0.37 & 87 & 598.3 & 353.5 & 336.62 & 13.8 & 0.70 & 152786 & 0.4 \\
\hline
\end{tabular}




\begin{tabular}{|c|c|c|c|c|c|c|c|c|c|c|c|c|c|}
\hline NAL-611* & Kistufell & 1.4908 & $53.4(3 \%)$ & -0.22 & 0.46 & 160 & 2370.3 & 345.9 & 1323.7 & 16.9 & 0.17 & 130454 & 4.6 \\
\hline NAL-688* & Eggert/Hrúthálsar & 2.5461 & $3.78(21 \%)$ & 2.23 & 0.36 & 89 & 791.2 & 313.5 & 127 & 8.9 & 0.24 & 3369 & 2.3 \\
\hline HS92-15* & Bláfjall & 1.4523 & $17.1(10 \%)$ & 0.05 & 0.53 & 138 & 2006.0 & 395.9 & 1636.7 & 10.8 & 0.069 & 8606 & 3.9 \\
\hline KVIH-1 & Kvíhólafjöll & 2.4120 & $0.17(87 \%)$ & 8.86 & 0.37 & 152 & 20.1 & 300.3 & 13.04 & 9.4 & 0.10 & 32.8 & 135.5 \\
\hline dup & & 2.8666 & $9.73(12 \%)$ & 0.72 & 0.40 & 214 & & & & & & & \\
\hline HRD-1* & Herðubreið & 3.2930 & $12.4(8 \%)$ & 3.38 & 0.36 & 172 & 155.3 & 350.2 & 44.5 & 9.1 & 2.2 & 6044 & 1.3 \\
\hline dup & & 3.1737 & $2.93(24 \%)$ & -0.88 & 0.64 & 357 & & & & & & & \\
\hline \multicolumn{14}{|l|}{ ERZ } \\
\hline A11 & Hnottóttaalda & 2.6358 & $11.7(10 \%)$ & 2.52 & 0.45 & 178 & 2344.9 & 295.4 & 136.41 & 24.3 & 0.25 & & \\
\hline A13/ICE08R-09 & Skerðingar-1 & 3.3238 & $0.94(47 \%)$ & 4.07 & 0.35 & & 368.2 & 308.1 & 52.48 & 20.9 & 0.061 & & 4.1 \\
\hline A18/ICE08R-12 & Dór & 2.5061 & $18.3(5 \%)$ & 5.58 & 0.46 & 102 & 131.1 & 298.0 & 302.16 & 19.8 & 0.22 & & \\
\hline A20/ICE08R-15* & Kambsfell & 2.4489 & $49.4(2 \%)$ & 1.53 & 0.53 & 169 & 2894.2 & 323.0 & 597.3 & 20.3 & 0.29 & 190215 & 2.7 \\
\hline A21/ICE08R-16 & Near Kambsfell & 1.6751 & $54.1(3 \%)$ & 4.27 & 0.38 & 150 & 3557.7 & 302.6 & 1099.82 & 22.2 & 0.16 & 1457984 & 56.7 \\
\hline dup & & 1.7669 & $5.99(37 \%)$ & 7.87 & 0.38 & 135 & & & & & & & \\
\hline A22/ICE08R-17 & North of Valafell & 2.7285 & $25.1(5 \%)$ & 4.34 & 0.73 & 129 & 184.9 & 1094.8 & 1033.66 & 20.2 & 0.086 & 6700 & 16.3 \\
\hline dup & & 1.731 & $49.5(5 \%)$ & 1.10 & 0.53 & & & & & & & & \\
\hline A24* & Mið-Bálkafell & 2.543 & $14.8(8 \%)$ & 3.01 & 0.44 & 170 & 430.8 & 306.6 & 56.2 & 25.9 & 0.73 & 49075 & 7.1 \\
\hline A27 & North of Illakamur & 2.7225 & $18.9(6 \%)$ & 0.86 & 0.37 & 137 & 353.7 & 302.5 & 115.5 & 19.7 & 0.59 & 199895 & 41.0 \\
\hline A32 & Grænifjallgarður & 2.3276 & $2.03(41 \%)$ & 9.14 & 0.53 & & 97.6 & 301.5 & 132.44 & 18.1 & 0.061 & & 24.0 \\
\hline A35 & Sigalda & 2.5882 & $9.98(9 \%)$ & 11.96 & 0.15 & 104 & 20.2 & 322.0 & 193.15 & 20.6 & 0.18 & 13186 & 88.5 \\
\hline dup & & 3.1700 & $2.66(23 \%)$ & 13.14 & 0.42 & 226 & & & & & & & \\
\hline ICE08R-13* & Bláfjall & 2.0238 & $47.8(3 \%)$ & 4.34 & 0.33 & 161 & 1378.3 & 349.4 & 517.69 & 19.4 & 0.34 & 97129 & 2.9 \\
\hline dup & & 1.8988 & $21.5(6 \%)$ & 2.85 & 0.44 & 88 & & & & & & & \\
\hline \multicolumn{14}{|l|}{ SIVZ } \\
\hline TRI-1†* & Príhyrningur & 2.9369 & $10.4(8 \%)$ & -0.85 & 0.98 & 106 & 2496.3 & 306.5 & 472.8 & 25.3 & 0.06 & 39233 & 1.9 \\
\hline dup & & 1.8696 & $5.37(22 \%)$ & -0.23 & 0.38 & & & & & & & & \\
\hline TRI-2† & Príhyrningur & 2.7639 & 4.35 (22\%) & -2.91 & 0.36 & 380 & 866.7 & 298.0 & 122.6 & 25.7 & 0.10 & & \\
\hline TRI-3†* & Príhyrningur & 2.4588 & $20.3(6 \%)$ & 1.24 & 0.48 & 194 & 1094.1 & 308.3 & 203.3 & 25.2 & 0.28 & 67026 & 4.6 \\
\hline BHE-43† & Hekla-Ófærugil & 2.5799 & $14.4(12 \%)$ & 0.40 & 0.40 & 253 & 1113.3 & 298.2 & 306.5 & 20.7 & 0.16 & & \\
\hline BHE- $44 \dagger^{*}$ & Ytri-Rangá & 2.5227 & $16.6(9 \%)$ & 1.19 & 0.44 & 141 & 1723.6 & 302.9 & 274.1 & 21.0 & 0.21 & 135605 & 0.7 \\
\hline
\end{tabular}

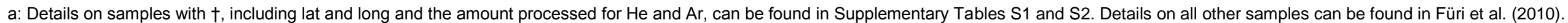
Samples with * are likely to have presereved nitrogen elemental and isotope characteristics of the Iceland mantle (see text for details). 
b: Blank contribution to $\left[\mathrm{N}_{2}\right]$ is given in (\%) after each number. Results reported in italics represent samples with blank contribution $>20 \%$. c: All $\mathrm{N}_{2} /$ Ar uncertainties are less than $10 \%$.

$\mathrm{d}$ : Ratios calculated by combining results from different aliquot.

e: Ratios calculated from the same aliquot as obtained from QMS. 
Table 2: End-member values adopted for DMM and the Iceland plume

\begin{tabular}{lccccc}
\hline End-member & ${ }^{3} \mathrm{He} /{ }^{4} \mathbf{H e}\left(\mathbf{R} / \mathbf{R}_{A}\right)^{\mathbf{a}}$ & $\boldsymbol{\delta}^{15} \mathbf{N}^{b}$ & ${ }^{4} \mathrm{He}^{40} \mathbf{A r}^{* \mathrm{c}}$ & $\mathbf{N}_{2} /{ }^{3} \mathbf{H e}^{\mathbf{d}}$ & $\mathbf{N}_{2}{ }^{40} \mathbf{A} \mathbf{r}^{* \mathbf{e}}$ \\
\hline DMM & $8 \pm 1$ & $-5 \pm 2$ & $1.4-4.8$ & $3.8 \pm 1.2\left(\times 10^{6}\right)$ & $138 \pm 65^{*}$ \\
Iceland & $37 \pm 2$ & $+3 \pm 3$ & $0.1-4.8$ & $1 \pm 6\left(\times 10^{10}\right)$ & $5 \pm 5\left(\times 10^{6}\right)$ \\
\hline
\end{tabular}

a: Values adopted from Hilton et al., (1999) and Graham, (2002).

b: Values adopted from Marty and Zimmerman (1999), Marty and Dauphas (2003a) and this study. See Section 5.2 for details.

c: Values adopted from Graham (2002), Hanyu et al., (2011) and Füri et al. (2010). See Section 5.1.2 for details.

d: Values adopted from Marty and Zimmerman (1999) and this study. See Section 5.2 for details.

e: Values calculated from Marty and Humbert (1997), Marty and Zimmerman (1999), Marty and Dauphas (2003a) and this study. See Sections 5.1.2 and 5.2 for details. 
FIGURES

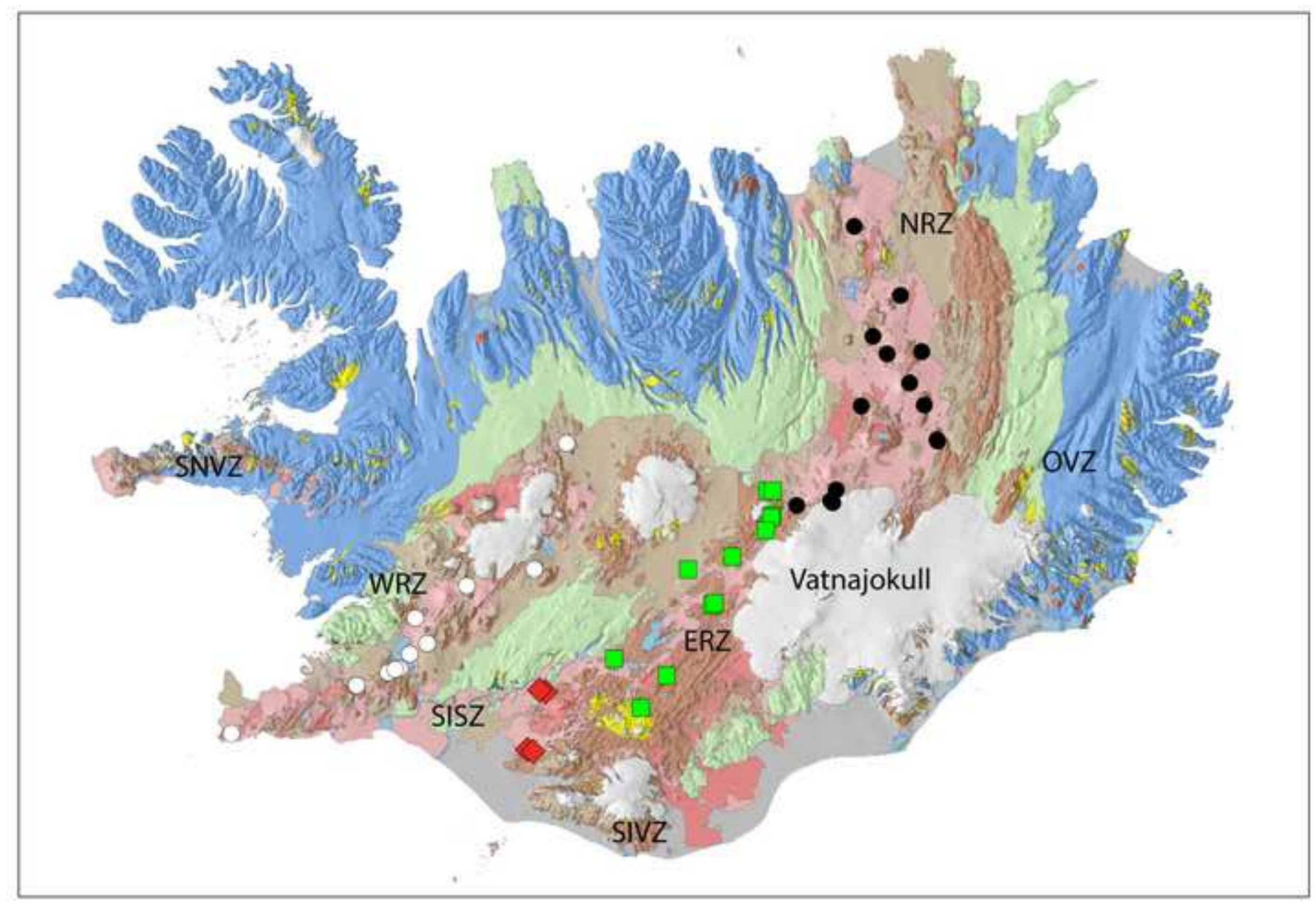

Figure 


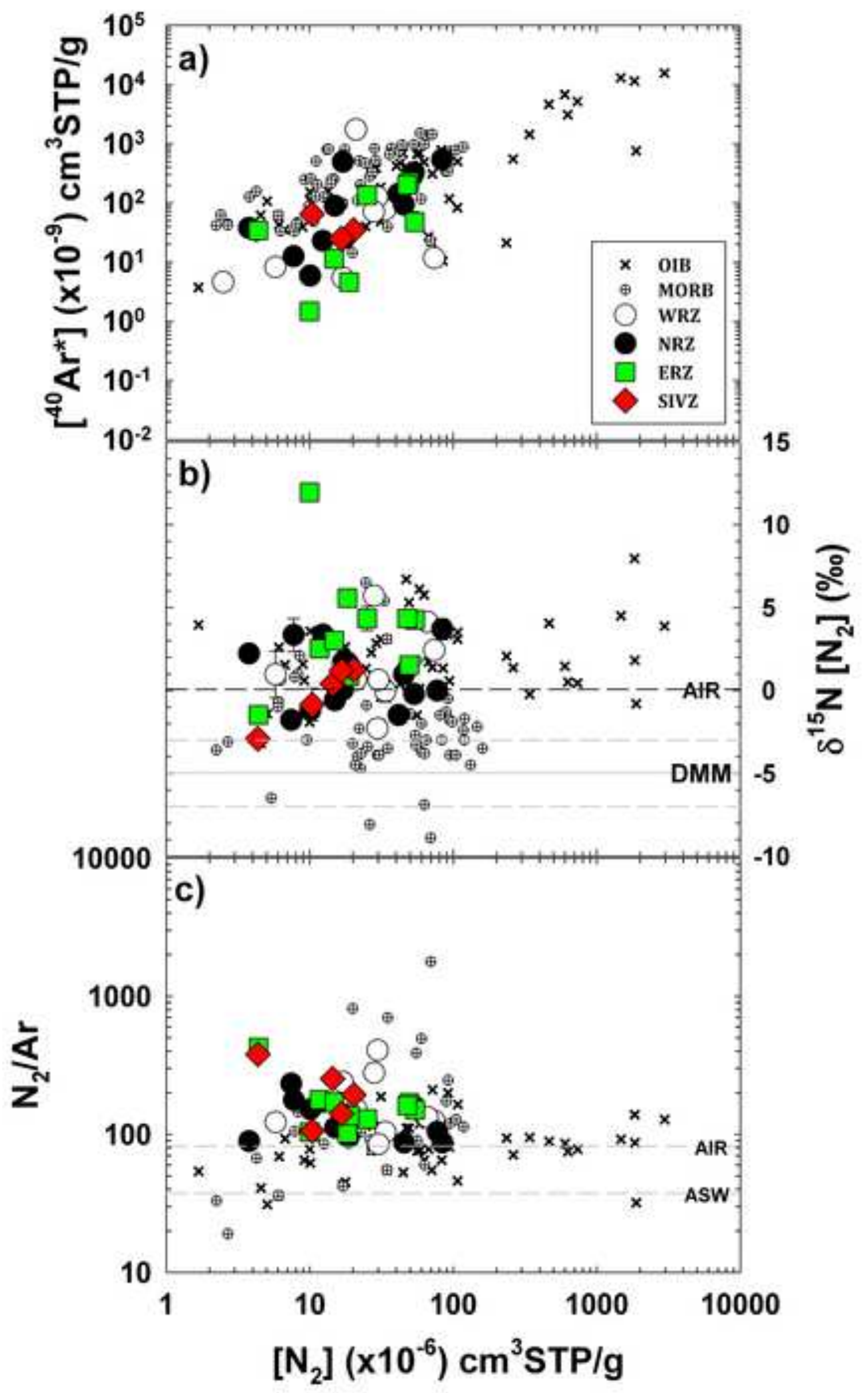

Figure 2 


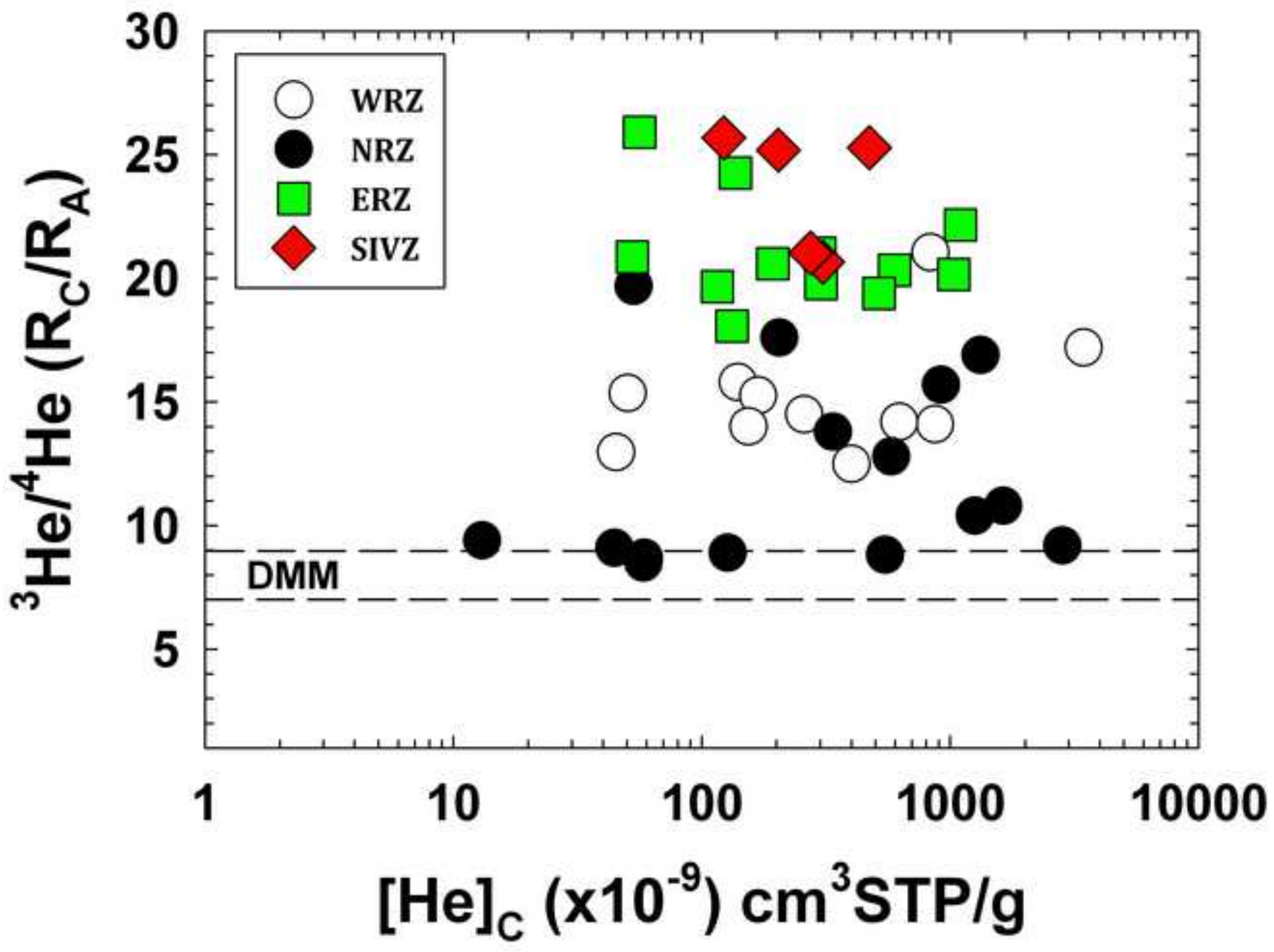




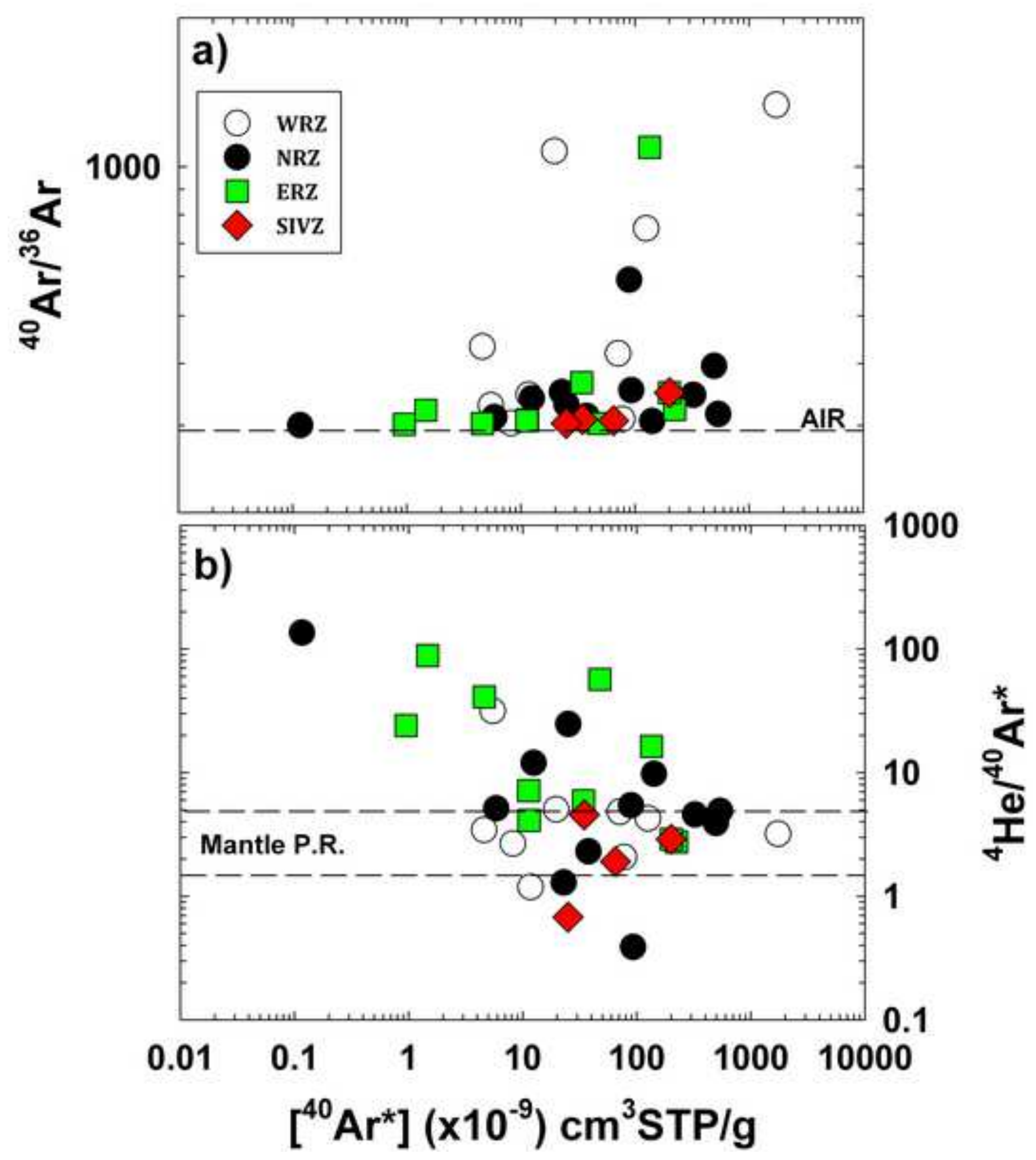

Figure 4 

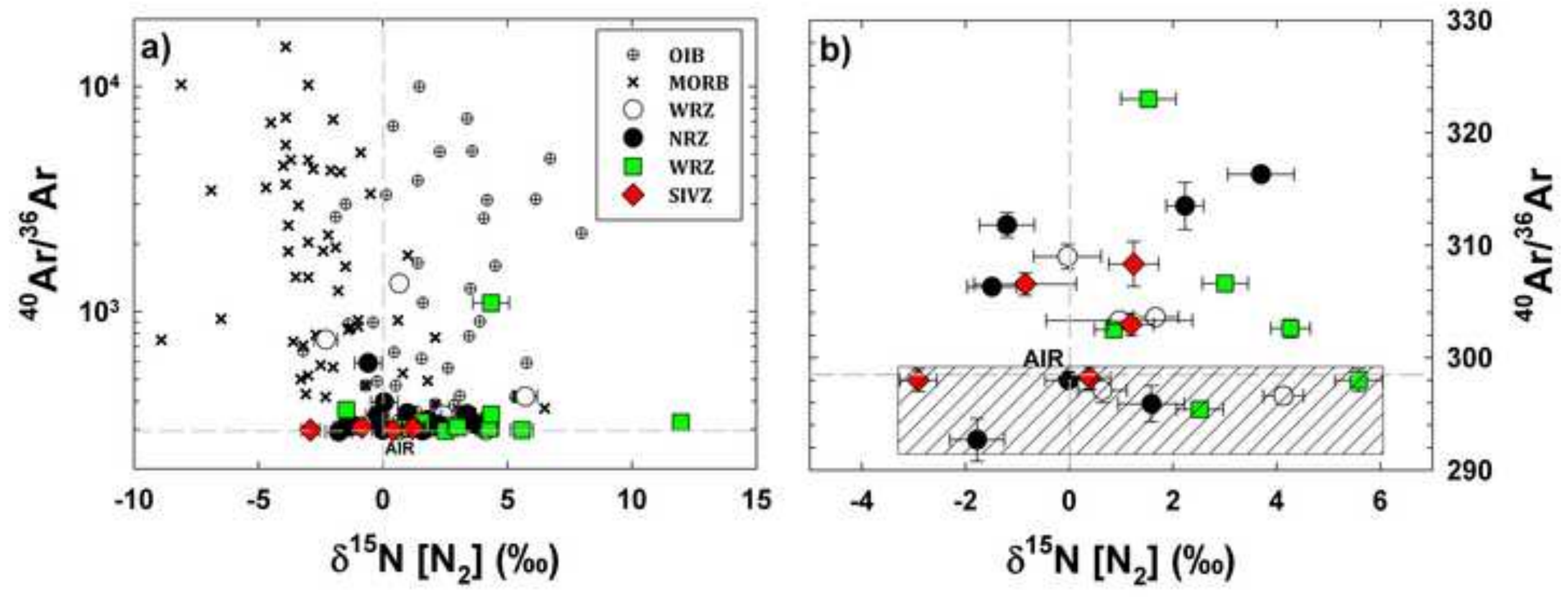


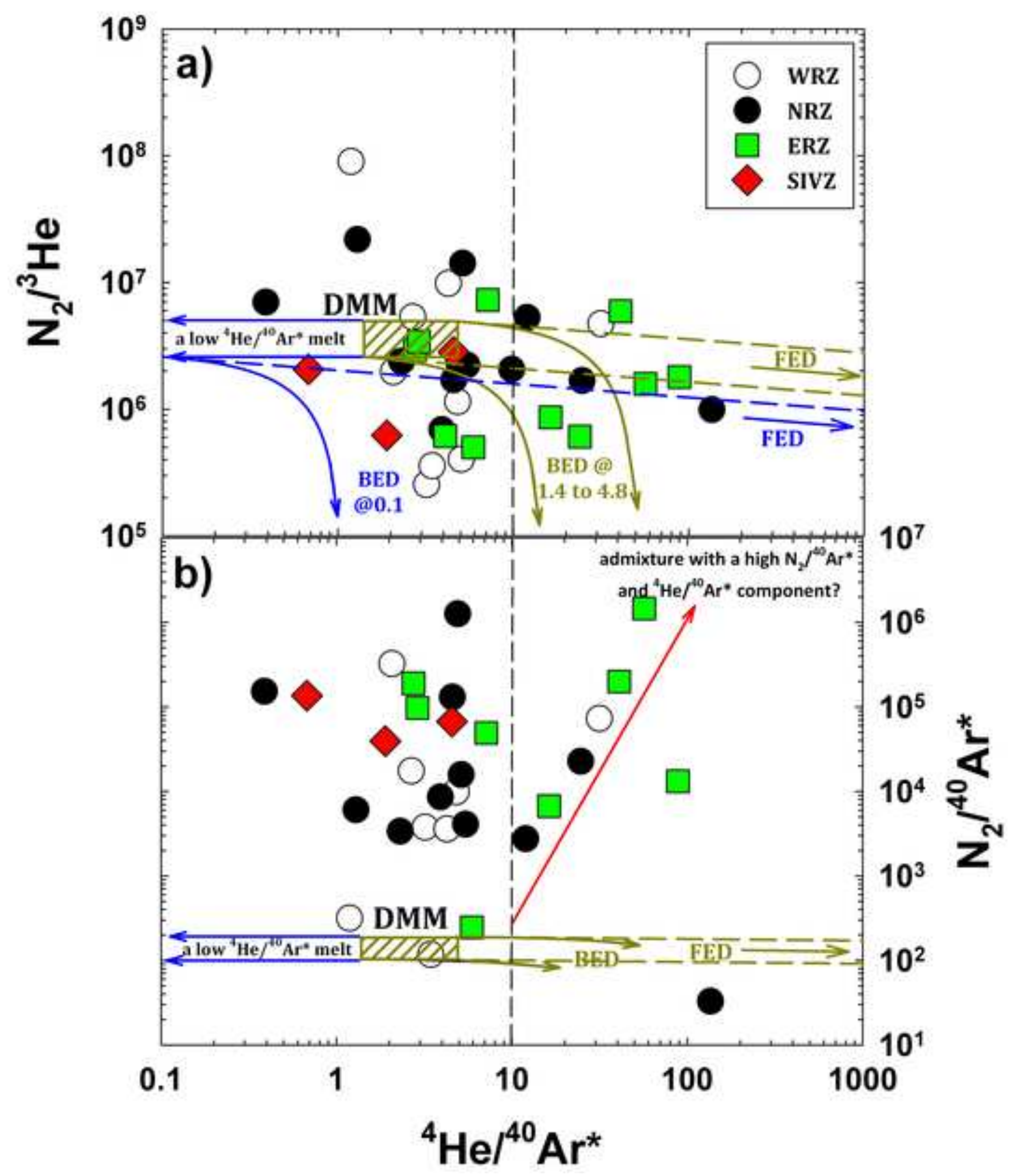




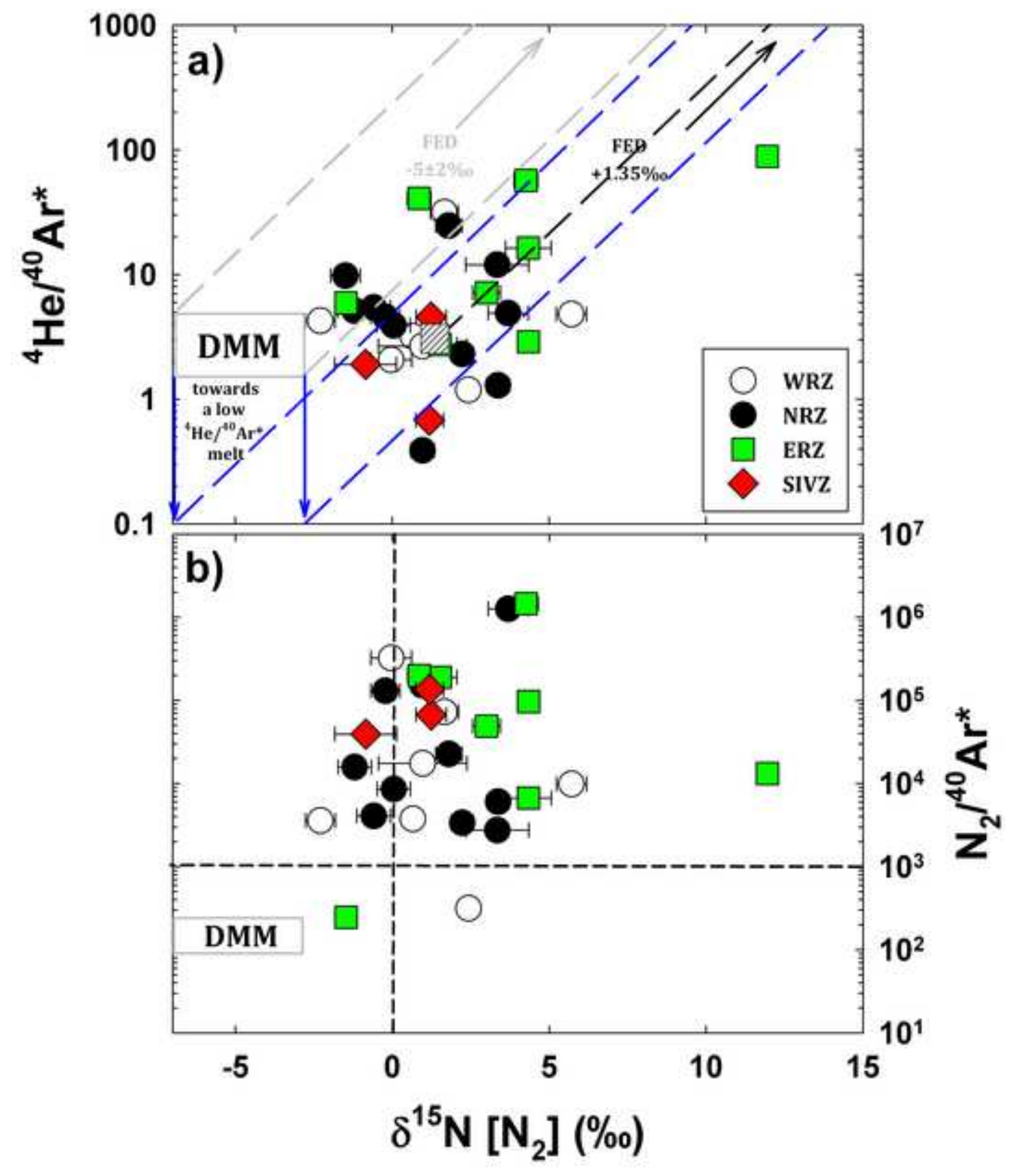

Figure 7 


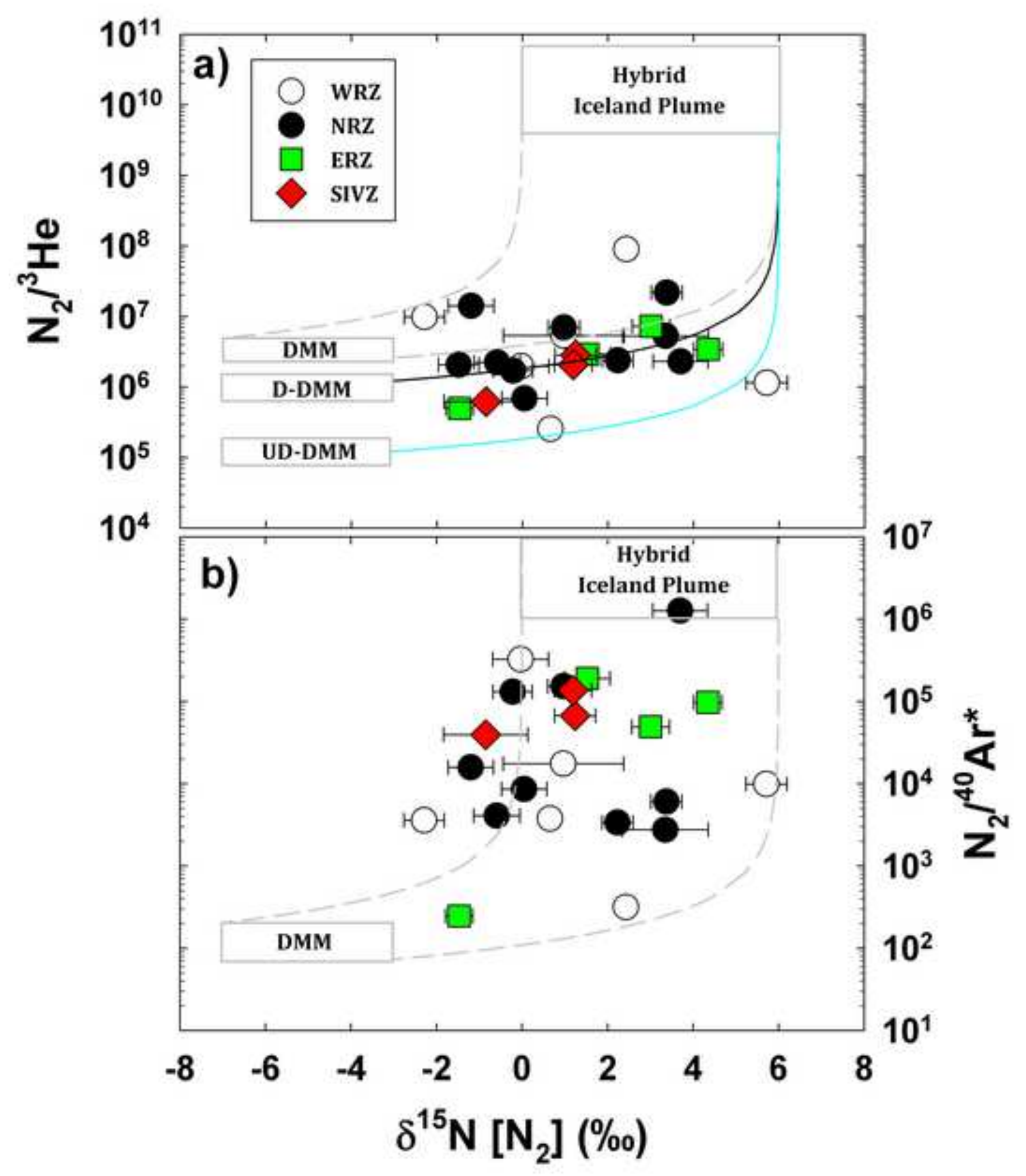

Figure 8 


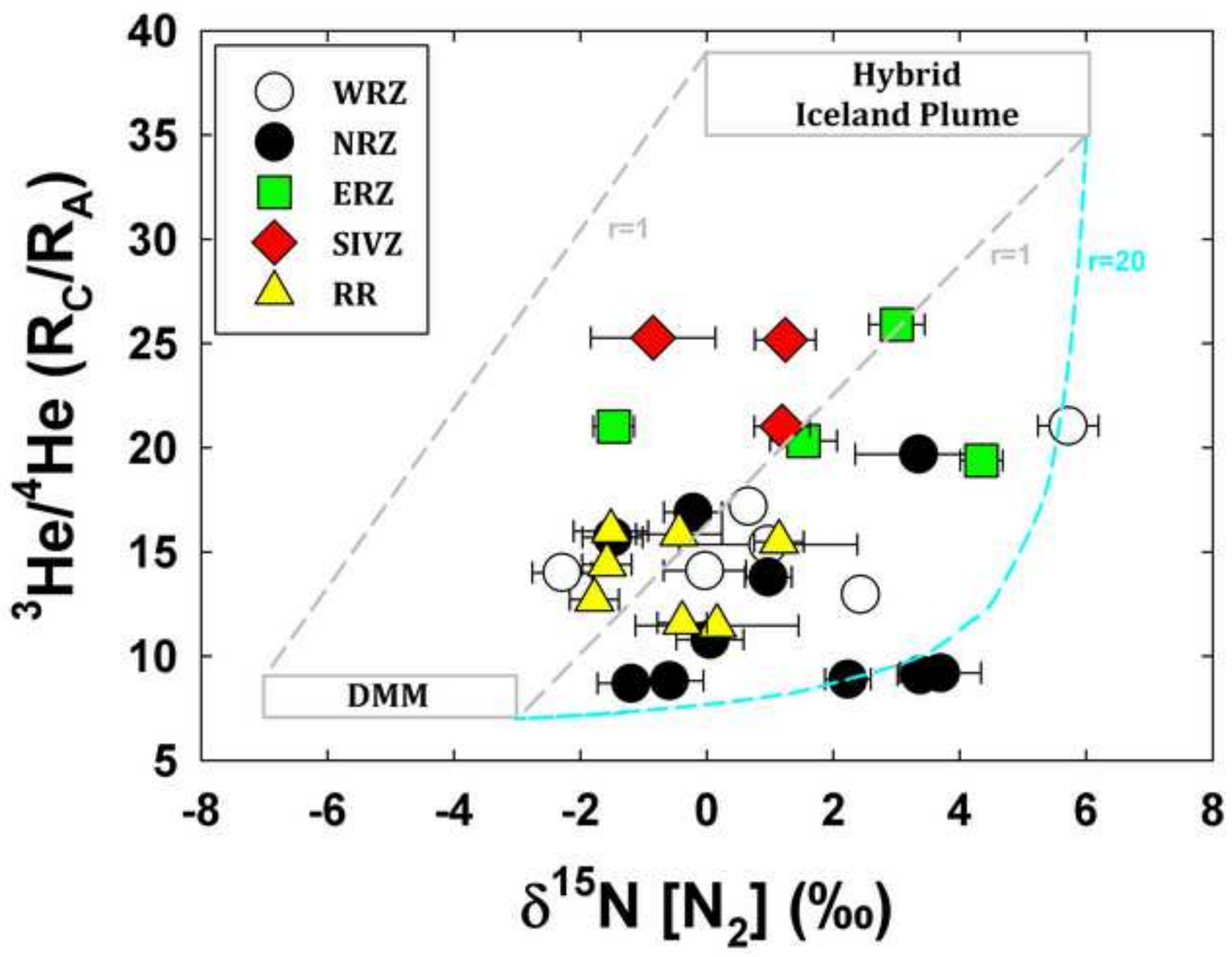

